\title{
Invited review: Caseins and the casein micelle: Their biological functions, structures, and behavior in foods ${ }^{1}$
}

\author{
C. Holt, ${ }^{2}$ J. A. Carver, $\dagger^{3}$ H. Ecroyd, $\ddagger$ and D. C. Thorn\# \\ *Institute of Molecular, Cell and Systems Biology, School of Life Sciences, University of Glasgow, Glasgow G12 8QQ, United Kingdom \\ †School of Chemistry and Physics, The University of Adelaide, Adelaide, SA 5005, Australia \\ $\ddagger$ School of Biological Sciences and Illawarra Health and Medical Research Institute, University of Wollongong, Wollongong, NSW 2522, Australia \\ \#Centre for Protein Engineering, University of Liège, 4000 Liège, Belgium
}

\begin{abstract}
A typical casein micelle contains thousands of casein molecules, most of which form thermodynamically stable complexes with nanoclusters of amorphous calcium phosphate. Like many other unfolded proteins, caseins have an actual or potential tendency to assemble into toxic amyloid fibrils, particularly at the high concentrations found in milk. Fibrils do not form in milk because an alternative aggregation pathway is followed that results in formation of the casein micelle. As a result of forming micelles, nutritious milk can be secreted and stored without causing either pathological calcification or amyloidosis of the mother's mammary tissue. The ability to sequester nanoclusters of amorphous calcium phosphate in a stable complex is not unique to caseins. It has been demonstrated using a number of noncasein secreted phosphoproteins and may be of general physiological importance in preventing calcification of other biofluids and soft tissues. Thus, competent noncasein phosphoproteins have similar patterns of phosphorylation and the same type of flexible, unfolded conformation as caseins. The ability to suppress amyloid fibril formation by forming an alternative amorphous aggregate is also not unique to caseins and underlies the action of molecular chaperones such as the small heat-shock proteins. The open structure of the protein matrix of casein micelles is fragile and easily perturbed by changes in its environment. Perturbations can cause the polypeptide chains to segregate into regions of greater and lesser density. As a result, the reliable determination of the native structure of casein micelles
\end{abstract}

\footnotetext{
Received March 19, 2013.

Accepted June 9, 2013.

${ }^{1}$ Bovine casein nomenclature follows the recommendations of the American Dairy Science Association Committee in their sixth revision as reported in Farrell et al. (2004).

${ }^{2}$ Corresponding author: carl.holt@glasgow.ac.uk

${ }^{3}$ Current address: Research School of Chemistry, College of Physical and Mathematical Sciences, The Australian National University, Canberra, ACT 0200, Australia.
}

continues to be extremely challenging. The biological functions of caseins, such as their chaperone activity, are determined by their composition and flexible conformation and by how the casein polypeptide chains interact with each other. These same properties determine how caseins behave in the manufacture of many dairy products and how they can be used as functional ingredients in other foods.

Key words: unfolded protein, molecular chaperone, calcium phosphate sequestration, amyloid fibril

\section{INTRODUCTION}

Caseins evolved from members of a group of secreted calcium (phosphate)-binding phosphoproteins (SCPP; Supplementary File, sections S1 and S2, available online at http://dx.doi.org/10.3168/jds.2013-6831; Kawasaki and Weiss, 2003; Rijnkels et al., 2003; Kawasaki et al., 2004, 2011; Lemay et al., 2009). In eutherian milks, at least 3 and normally 4 gene products are found; namely, $\alpha_{\mathrm{S1}^{-}}, \alpha_{\mathrm{S2}^{-}}, \beta-$, and $\kappa^{-} \mathrm{CN}$, but in some species 2 quite different $\alpha_{\mathrm{S}^{2}} \mathrm{CN}$-like genes are active, raising the total number of gene products to as many as 5. In this review, we attempt to put caseins into an evolutionary and functional context provided by comparisons with other SCPP and less closely related proteins with similar biological functions. The scope of the review is summarized in Figure 1 and covers the major events of protein association leading to the formation of the casein micelle in milk and of a casein clot in the stomach of the neonate. Subsequent events of protein digestion and absorption are excluded. The insights gained from the study of caseins as unfolded SCPP are also used in a more speculative discussion of the behavior of caseins during the manufacture of milk products.

In only a few years, the study of unfolded proteins has generated a huge body of new knowledge and understanding of this large and important group (Rose, 2002; Tompa, 2010). Our view is that unfolded proteins provide better models for describing caseins than either surfactants or globular proteins. Like many other un- 


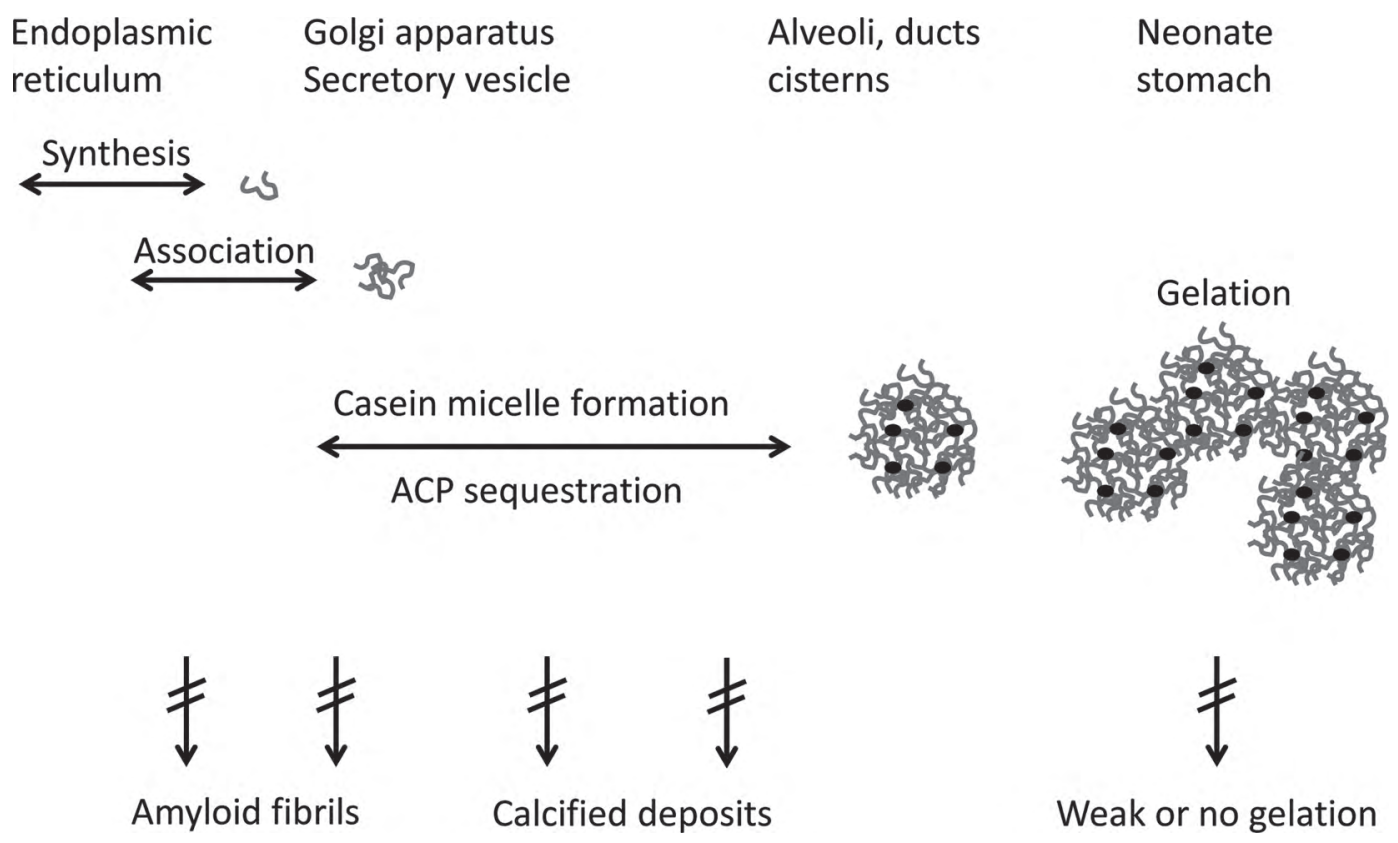

Figure 1. Scope of the review. To avoid amyloidosis through the formation of amyloid fibrils by caseins, a mixture of 3 or more different caseins associate by many alternative and nearly equivalent interactions to form amorphous aggregates known as casein micelles. To prevent calcium phosphate precipitation, nanoclusters of amorphous calcium phosphate are sequestered by the calcium-sensitive caseins within the casein micelles. In the stomach of the neonate, casein micelles can form a gel either by $\mathrm{pH}$ reduction to around the isoelectric point of casein or by limited and specific cleavage of $\kappa$-casein by an aspartate proteinase.

folded proteins, bovine $\kappa$ - and $\alpha_{\mathrm{S}_{2}} \mathrm{CN}$ can each form highly structured amyloid fibrils (Farrell et al., 2003; Thorn et al., 2005, 2008; Léonil et al., 2008). Caseins also show similarities to the small heat-shock proteins (sHsp) in being able to act as molecular chaperones (Morgan et al., 2005). The molecular chaperone action of the caseins is facilitated by their unfolded and flexible conformation. When interacting with a fibrilforming target protein, for example, many alternative and nearly equivalent interactions of low sequence specificity compete with the sequence-specific interactions involved in forming the cross- $\beta$-sheet structures of fibrils. In consequence, an amorphous aggregate is formed, rather than a fibril.

The properties of caseins as molecular chaperones provide an insight into the nature of the protein-protein interactions involved in the self-association of individual caseins and in the formation of amorphous aggregates by mixtures of caseins. Hence, in mixtures with other caseins, the chaperone action of the caseins prevents or limits (Lencki, 2007; Thorn et al., 2008) amyloid fibril formation. The sequences responsible for casein intermolecular interactions are mainly the Proand Gln-rich (P,Q-rich) sequences encoded by longer exons (Supplementary File, section S2; http://dx.doi. org/10.3168/jds.2013-6831). However, a notable exception is the C-terminal sequence of $\kappa$ - $\mathrm{CN}$ (the macropep- tide), which does not readily form inter-protein interactions because of its higher content of the hydroxy-amino acids Ser and Thr (S,T-rich) and negatively charged residues. Posttranslational modifications of the primary structure by glycosylation and phosphorylation further increase its charge density and hydrophilicity. The remainder of $\kappa-\mathrm{CN}$ (para- $\kappa-\mathrm{CN}$ ) is mostly composed of $\mathrm{P}, \mathrm{Q}$-rich sequences that can bind to similar sequences in other caseins. As a result, whereas $\kappa-\mathrm{CN}$ acts to limit the size of amorphous aggregates formed by mixtures with other caseins and calcium ions, para- $\kappa-\mathrm{CN}$ causes a similar mixture to precipitate or form a gel (Waugh and Talbot, 1971). With the appropriate number of sequestered nanoclusters of amorphous calcium phosphate (ACP), whole casein forms the amorphous aggregate known as the casein micelle. In the casein micelle, virtually all the fibrillogenic $\alpha_{\mathrm{S} 2}-\mathrm{CN}$ is bound to the nanoclusters of sequestered ACP (Holt, 2004) to further reduce its propensity to form fibrils.

Besides caseins (Holt et al., 1996, 1998; Holt, 2004; Little and Holt, 2004), a number of other SCPP and a few non-SCPP have the unfolded conformation and short, multi-phosphorylated, sub-sequences called phosphate centers (PC) that are needed to sequester ACP and form stable complexes (Holt et al., 2009). Solutions containing this type of sequestered calcium phosphate are thermodynamically stable provided there is a stoi- 
chiometric excess of the sequestering PC. Only bovine milk data have been analyzed quantitatively, and it has been shown (see Figure 6 of Holt, 2004) that most individual cow milks have an excess of PC. The ACPsequestering action of caseins in milk can therefore be regarded as an adaptation of an antecedent function shared with other SCPP such as osteopontin (OPN) in the formation of stable biofluids and the control of biomineralization (Holt, 2013).

A diversity of views on the structure of the casein micelle have been expressed in recent reviews from the colloid and food science perspective (de Kruif and Holt, 2003; Horne, 2008; Dalgleish and Corredig, 2012; McMahon and Oommen, 2012) and from a somewhat different biological perspective to that developed here (Farrell et al., 2006a). In this review, we consider the structure of the casein micelle in relation to 3 of its recognized biological functions. The first is the control of calcium phosphate precipitation through ACP sequestration, the second is the suppression of amyloid fibril formation, and the third is the nutrition of the neonate. The first 2 functions relate primarily to the mother and her ability to lactate repeatedly throughout her reproductive life. Pathological calcification or amyloidosis of the mammary gland would threaten not just the life of the mother's neonate but also, and arguably more importantly, her prospects for future reproductive success. Holt and Carver (2012) suggested that the casein micelle was therefore one of the principal means by which a scarcely nutritious protolacteal fluid could safely evolve into highly nutritious milk without, at any stage, harming the reproductive prospects of the mother.

\section{CASEINS AS UNFOLDED PROTEINS}

\section{Secreted Calcium (Phosphate)-Binding Phosphoproteins}

The evolution of caseins from other SCPP is discussed in Supplementary File, section S1 (http://dx.doi. org/10.3168/jds.2013-6831). Caseins are fairly typical SCPP in that they have both highly phosphorylated sequences and P,Q-rich sequences. For example, OPN and 4 other human SCPP have PC-like sequences; the $\mathrm{N}$-terminal plasmin phosphopeptide of bovine OPN (OPN 1-149) contains $3 \mathrm{PC}$ and will sequester ACP to form a type of nanocluster complex in much the same way as caseins and PC-containing casein phosphopeptides (Holt et al., 2009). The salivary gel-forming mucin MUC-7 and at least 3 other lachrymal and salivary human SCPP are composed almost entirely of Pro-, Tyr-, Ser-, and Thr-rich sequences, comparable in composition to the macropeptide of $\kappa$-CN (Supplementary
Table S4; http://dx.doi.org/10.3168/jds.2013-6831). Salivary statherin has both a phosphorylated N-terminal sequence, able to bind to tooth enamel, and a Pro-, Gln-, and Tyr-rich C-terminal sequence able to bind to bacterial fimbriae (Masica and Gray, 2009). The dental SCPP amelogenin contains P,Q-rich sequences similar in composition to those in caseins. It can self-associate entropically, rather like $\beta$ - or $\kappa-\mathrm{CN}$, to form monodisperse nanospheres of radius about $15 \mathrm{~nm}$ (Lakshminarayanan et al., 2007; Zhang et al., 2011). After further proteolytic processing, it can also form a number of extended mesostructures that affect or guide calcium phosphate crystal growth in dental enamel (see reviews by Fincham et al., 1999; Margolis et al., 2006).

\section{Primary, Secondary, and Tertiary Structures of Caseins}

Among casein orthologs, there are relatively few conserved AA sequences other than the signal peptides. Genomic sequences, however, show that exon length and translated AA composition are well conserved. The exon structure therefore provides a rational basis for the classification of functional sequences in caseins. Whereas the number of exons varies widely, even among orthologs, these can be divided into just 6 types (Kawasaki et al., 2011); namely an exon encoding the signal peptide, a short exon type encoding the C-terminal sequence, and 3 types of short, internal exons encoding all the PC and their hydrophilic flanking sequences. In addition, the P,Q-rich sequences are encoded by longer exons that appear to have grown by intra-exonic tandem duplications (Holt and Sawyer, 1993). Reasonable alignments of orthologous caseins and even close paralogs can be made based on the conservation of exon boundaries (Martin et al., 2003). The alignment of 49 calcium-sensitive casein sequences in Supplementary File, section S2 and Table S2 (http:// dx.doi.org/10.3168/jds.2013-6831) reveals the overall architecture of caseins. The fully conserved features of all caseins appear to be the signal peptide at the Nterminus and a $\mathrm{P}, \mathrm{Q}$-rich sequence at or near the C-terminus. All the potential PC have 2 flanking hydrophilic sequences unless the $\mathrm{PC}$ is $\mathrm{N}$-terminal after cleavage of the signal sequence, when there is only 1 such sequence. The PC and its flanking hydrophilic sequences comprise a potential ACP-binding motif. The calcium-sensitive caseins have between 0 and 3 potential ACP-binding motifs. Thus, $\beta$-CN mostly have $1, \alpha_{\mathrm{S} 2}$ - CN mostly 3 , and $\alpha_{\mathrm{S} 1}-\mathrm{CN}$ mostly 2 potential ACP-binding motifs.

The AA sequences of SCPP have a low level of complexity and are biased in composition toward forming an unfolded conformation. Sophisticated, multivariate algorithms based upon AA sequences rather than com- 
position have confirmed experimental findings that all SCPP are unfolded to a large degree (Naganagowda et al., 1999; Fisher et al., 2001; Syme et al., 2002; Buchko et al., 2008; Schedlbauer et al., 2008; Aichmayer et al., 2005; Delak et al., 2009; Holt et al., 2009) with a predominance of the poly-L-proline type II (PP-II) secondary structure (Supplementary File, section S4.1; http://dx.doi.org/10.3168/jds.2013-6831).

\section{Quaternary Structures and the Hydrophobic Effect}

The reputation of caseins as hydrophobic proteins is undeserved. It was acquired originally from a supposed similarity between the self-association behavior of casein, particularly $\beta$ - and $\kappa-\mathrm{CN}$, and the formation of surfactant micelles (Fox and Brodkorb, 2008). It was reinforced by the use of the Bigelow hydrophobicity scale (Bigelow, 1967), which classified $\beta$ - and $\kappa-\mathrm{CN}$ as being among the most hydrophobic proteins known to science. The Bigelow scale is no longer used; it contains a number of errors and omissions, including an unusually high hydrophobicity for the Pro residue compared with the more widely accepted value, close to that of the hydrophilic residue His, in the scale of Kyte and Doolittle (1982). Proline is not classified as a hydrophobic residue; it is seldom found in the core of globular proteins (Macarthur and Thornton, 1991; Le Questel et al., 1993) or in clusters of hydrophobic residues (Arunachalam and Gautham, 2008), partly because of the restricted range of Ramachandran angles accessible to imino acids and partly because the backbone carbonyl moiety is an excellent H-bond acceptor, making the residue more hydrophilic than its hydrophobicity would suggest, even on the scale of Kyte and Doolittle (1982). Likewise, the side chain of Gln can act as an $\mathrm{H}$-bond acceptor and donor so the energetic cost of desolvating Gln is high. It too is rarely found in the core of globular proteins (Le Questel et al., 1993). A nice illustration of the hydrophilicity of Pro is that Pro-rich oligomers tend to be quite soluble in aqueous solvents (Léonil et al., 1994). Caseins are surface active and will preferentially locate at hydrophobic interfaces, but they are readily displaced by denatured whey proteins (Dalgleish et al., 2002). When measured by the scale of Kyte and Doolittle (1982), caseins are, like the vast majority of unfolded proteins, more hydrophilic than almost all globular proteins (Uversky and Dunker, 2010).

All of the caseins have an amphipathic character because they contain one or more P,Q-rich sequences, which are less highly charged than the remainder of the polypeptide chains. For example, $\beta-\mathrm{CN}$ has been compared to a soap molecule with a hydrophilic Nterminal "head," comprising the PC and its flanking sequences, and a hydrophobic "tail" comprising a P,Q- rich sequence. The self-association of $\beta$ - and $\kappa-\mathrm{CN}$ has, accordingly, been likened to formation of soap micelles, where the driving force is provided by the hydrophobic interactions of the tail regions. The analogy with soap molecules is, however, of limited value. Protein sequences, even if they comprise hydrophobic residues, can interact through main-chain and side-chain H-bonds and other interactions not present in soap molecules. Moreover, the structures of casein micelles are different from those formed by simple soaps or copolymer detergents. As Dalgleish pointed out (Dalgleish, 2011; Dalgleish and Corredig, 2012), caseins associate to form highly solvated structures, not the anhydrous compact domains of hydrocarbon chains in soap micelles.

The thermodynamic characteristics of micelle formation by detergents include a positive enthalpy change, an entropy increase, cooperativity, a large increase of specific heat, and an increase of molar volume. The association behavior of $\beta-\mathrm{CN}$ shows these characteristics only in part (see Portnaya et al., 2006, and references therein). Thus, association is endothermic but poorly cooperative and the specific heat of micellization changes sign with temperature. Self-association of $\kappa-\mathrm{CN}$ is more cooperative than that of $\beta-\mathrm{CN}$, but is athermal (Payens and Vreeman, 1982). Thus, the interaction of $\beta$ - and $\kappa-\mathrm{CN}$ cannot be likened to soap micelle formation by detergents without undue simplification.

The hydrophobic effect was originally invoked by Kauzmann (1959) to provide the driving force for the transition of a polypeptide chain from a disordered and solvent-exposed state to one where the globular fold has a substantial anhydrous core. It was thought at the time that a change from main-chain $\mathrm{H}$-bonding to water molecules in the unfolded state to main-chain to main-chain H-bonding in the core would be energetically neutral. As defined by Kautzmann (1959), the hydrophobic interaction in proteins is a property only of the side chains of residues. More recent work on the nature of the free energy changes in protein folding has recognized the difficulty of separating the hydrophobic effect derived from the desolvation of side chains from the $\mathrm{H}$-bonding interactions and desolvation of the main chain, particularly as the latter can display the same thermodynamic signatures as the hydrophobic effect (Cooper 2000, 2005; Djikaev and Ruckenstein, 2009). For example, molecular dynamics simulations showed that perturbation of the structure of the water shells around the main chain of a poly-Ala sequence, going from its stable PP-II conformation to a $\beta$-strand, was reminiscent of the hydrophobic effect (Mezei et al., 2004). In summary, an endothermic or thermoneutral interaction of protein chains cannot be assumed to be caused by the hydrophobic effect operating between side chains. Use of a term such as "entropic interac- 
tion" is more appropriate for an endothermic protein association process when a distinction cannot be drawn between main-chain and side-chain interactions.

The low sequence specificity of their interactions and their PP-II conformation make P,Q-rich sequences in proteins particularly well suited to forming extended, hydrated structures (Cubellis et al., 2005). The viscoelastic properties of mucus, slimes, and other viscous biofluids are determined in large part by the formation of extended and entangled structures by mucins such as the SCPP mucin 7 (Supplementary Table S4, http:// dx.doi.org/10.3168/jds.2013-6831; Schenkels et al., 1995; Thornton et al., 2008; Senapati et al., 2010). Likewise, P,Q-rich proteins readily form gels; for example, the seed storage prolamins wheat gliadin and barley hordein (Shewry and Halford, 2002) or the plant cell wall extensins (Newman and Cooper, 2011). Extended hydrated structures and low sequence specificity both point to a predominance of main-chain interactions mediated by direct $\mathrm{H}$-bonding or through bridging water molecules.

\section{Interaction of Pro-Rich PP-II Sequences with Globular Domains}

In the formation of extended structures between unfolded P,Q-rich proteins, the nature of the inter-chain contacts is not precisely known. Clues to the nature of the interactions come from high-resolution structural studies involving the binding of Pro-rich PP-II conformers to globular protein domains. Originally, Pro-rich PP-II sequences were known only as spacer or linker sequences between folded domains in multidomain proteins of known structure. However, as the study of unfolded proteins has expanded, it has become increasingly well recognized that their low sequence specificity is important in a large number of low affinity protein-protein interactions in signal transduction, protein transcription, and other pathways (Sudol, 1998; Macias et al., 2002; Musacchio, 2002; Hicks and Hsu, 2004; Polverini et al., 2008; Zhao et al., 2010). Common domains such as WW (named for a conserved Trp-Trp; Schleinkofer et al., 2004), GYF (conserved Gly-Tyr-Phe; Gu et al., 2005), and Src homology 3 (SH3) can bind and respond to a broad range of Pro-rich sequences. They do so through shallow hydrophobic sites but the molecular details of the interaction and thermodynamic measurements demonstrate the overwhelming importance of H-bonding. The best characterized example is the shallow binding site of the SH3 domain, which is formed from many aromatic residues (Macias et al., 2002). A Pro-rich peptide in the PP-II conformation can fit into the binding groove with stacking of the aromatic and Pro "side chains." A recently reported crystal structure located water molecules in an SH3 binding pocket when it was occupied by a Pro-rich ligand (Martin-Garcia et al., 2012). Well-ordered water molecules were found at the binding interface forming $\mathrm{H}$-bonds with the SH3 domain or its ligand and acting as bridges between them. The universally large negative enthalpy of Pro-rich ligand binding to SH3 domains suggests that the H-bonding interactions rather than the hydrophobic effect are dominant.

\section{Summary of Casein P,Q-Rich Sequence Interactions}

To summarize, the self-association of $\beta$ - or $\kappa$-casein is entropic in character but there is no evidence of any large-scale transition from an unfolded state to a condensed and anhydrous globular fold in their micelles, nor, indeed, in casein micelles. The thermodynamic signatures of $\beta$ - and $\kappa$-casein self-association do not establish that the hydrophobic effect is the only, or even the predominant, driving force, as maintained by Horne in his so-called dual binding model (Horne, 2002,2008 ), because they could equally well arise from the formation of a network of H-bonds (Cooper, 2000, 2005). Indeed, it would be naïve to assume that main chain H-bonding was not also of importance in casein interactions and in many cases it may be the dominant form of interaction between $\mathrm{P}, \mathrm{Q}$-rich sequences. The source of the association behavior leads to low affinity binding, which will therefore be dynamic and subject to change as the environment of the micelles changes. Two examples illustrate the weak nature of the caseincasein interactions: the cleavage of just a few residues from the P,Q-rich C-terminus of $\beta$-casein dramatically reduces its tendency to associate into micelles (Qi et al., 2005 ), and the profound degree of dissociation of casein micelles that occurs when the sequestered nanoclusters of ACP are removed while other important parameters affecting association are kept constant (Holt, 1998).

\section{CASEINS AS MOLECULAR CHAPERONES}

\section{Prevention of Protein Aggregation by Molecular Chaperones}

The in vivo production and maintenance of proteins in a soluble and biologically active state requires the coordinated action of a number of systems spanning transcription, RNA processing and transport, and protein translation, folding, transport, and, ultimately, degradation. A fine balance exists between keeping a protein in solution at a sufficiently high concentration to meet biological requirements and its precipitation, resulting in the possible formation of an insoluble and inactive deposit (Baldwin and Zimm, 2000; Vendruscolo 
et al., 2011). The production of deposits in the form of plaques and inclusion bodies has been associated with a variety of so-called protein conformational or protein misfolding diseases (e.g., Alzheimer's disease, Parkinson's disease, type-II diabetes, and cataracts). An insoluble deposit can arise by the association of a partially folded or misfolded protein into either a disordered (amorphous) or a highly ordered amyloid fibril containing a cross- $\beta$-sheet structure. Above a critical size, fibrils can precipitate from solution (Harper and Lansbury, 1997; Dobson, 1999; Stranks et al., 2009). Amyloid fibril formation and structure are considered in further detail in Supplementary File, section S3 http://dx.doi.org/10.3168/jds.2013-6831). In many cases, the aggregation of proteins, particularly into amyloid fibrils, is cytotoxic and so it was important in the evolution of milk to avoid this potential source of cytotoxicity.

Arguably, the most important mechanism responsible for ensuring that proteins attain and remain in their biologically active conformation is through the action of molecular chaperones (Barral et al., 2004; Hartl et al., 2011). A molecular chaperone is a protein that can interact with a target protein to either stabilize the target protein against aggregation ("holdase" chaperones) or help it acquire its native conformation ("foldase" chaperones; Hartl et al., 2011). All molecular chaperones can interact with a range of target proteins in a manner that has low sequence specificity. Holdase and foldase chaperones often work in synergy. A holdase chaperone typically forms a high-molecular-mass complex with a partially folded state of a target protein. Formation of the complex prevents the indefinite self-association of the target protein. Examples include the intracellular sHsp and the extracellular chaperone clusterin. The activity of holdase chaperones does not require ATP (Carver et al., 2003; Ecroyd and Carver, 2009). Foldase chaperones (e.g., Hsp60 or Hsp70) actively assist in the folding of target proteins, often by interacting with the partially folded protein as it is bound to a holdase in a high-molecular-mass complex. The refolding activity of foldase chaperones is dependent on ATP hydrolysis.

\section{The Chaperone Action of Caseins}

Caseins function as holdase molecular chaperones. Thus, the formation of the amorphous bovine casein micelle prevents the potentially harmful formation of amyloid fibrils by the specific self-association of $\alpha_{S^{-}}$ and $\kappa_{-} \mathrm{CN}$ (see the Casein Amyloid Fibrils section). In this case, the target protein is another casein. Moreover, caseins can interact with and stabilize noncasein proteins such as $\beta$-LG under conditions of stress arising from, for example, heat or pressure treatments.
The initial report that $\alpha_{\mathrm{S}}$-CN stabilized and prevented the aggregation and precipitation of heat-stressed proteins, including milk whey proteins (Bhattacharyya and Das 1999), has been followed by a number of in vitro studies of the chaperone action of individual caseins and casein micelles with target proteins under different stress conditions (reviewed in Yong and Foegeding, 2010). To date, most of the work has used standard light scattering or fluorescence-based assays to monitor protein aggregation. It is necessary to take what has been learned from these studies and utilize more complex assays to investigate this chaperone activity in physiologically relevant biological fluids and tissues.

As with other well-characterized holdase chaperone proteins, such as the sHsp (Carver et al., 2003; Haslbeck et al., 2005), caseins contain regions that are dynamic, malleable, and flexible as a consequence of their unfolded conformation. Furthermore, the casein micelle is similar to the sHsp oligomer in being a porous structure with many water-filled cavities and channels (Haslbeck et al., 2005; Trejo et al., 2011; Hanazono et al., 2012). Collectively, these properties facilitate casein interaction with, and binding to, a wide range of destabilized target proteins. In common with other molecular chaperones (Guha et al., 1998), bovine $\alpha_{\mathrm{S1}^{-}}$and $\beta-\mathrm{CN}$ contain a high percentage of Pro residues (9 and $18 \%$ of the AA sequence, respectively) and lack intramolecular disulfide bridges, factors that contribute to their open conformation. The chaperone action of sHsp is predominantly mediated through the interaction of hydrophobic sequences in the sHsp and hydrophobic sequences in the target proteins that become exposed during misfolding. The equivalent interactions between caseins are likely to involve the P,Q-rich sequences. The chaperone action of caseins will likely involve the interaction of $\mathrm{P}, \mathrm{Q}-\mathrm{rich}$ sequences in the caseins with exposed hydrophobic sequences in the partially folded target protein.

The hydrophilicity of the phosphorylated residues and flanking sequences (Supplementary Table S3; http://dx.doi.org/10.3168/jds.2013-6831) contribute to the open and flexible conformation of caseins and this helps to stabilize the high-molecular-mass complexes formed between caseins and target proteins during chaperone action. Consistent with this, dephosphorylation of $\alpha_{S^{-}}$and $\beta-C N$ reduces their ability to prevent the amorphous aggregation of a number of target proteins (Koudelka et al., 2009).

Like sHsp, caseins are promiscuous chaperones: they stabilize a range of unrelated target proteins from amorphous aggregation induced by heat, reduction, and UV-induced stress (Bhattacharyya and Das, 1999; Matsudomi et al., 2004; Morgan et al., 2005; Zhang et al., 2005; Hassanisadi et al., 2008; Koudelka et al., 
2009; Treweek et al., 2011). Moreover, $\alpha_{\mathrm{S1}^{-}}$and $\beta-\mathrm{CN}$ can also prevent the formation of fibrillar structures by target proteins, including $\alpha_{\mathrm{S}^{-}}$and $\kappa-\mathrm{CN}$ (Thorn et al., 2005, 2008), ovalbumin (Khodarahmi et al., 2008), and amyloid- $\beta$ peptide (Carrotta et al., 2012). Fibril formation by $\kappa-\mathrm{CN}$ is cytotoxic to PC-12 cells grown in culture but the effects are inhibited by $\alpha_{S^{-}}$or $\beta-\mathrm{CN}$ (Dehle et al., 2010). More recently, it has been shown that $\alpha_{S_{2}}-\mathrm{CN}$ is also toxic to PC-12 cells and the neuronal cell line SH-SY5Y [Kegomoditswe Regoeng (University of Adelaide, Australia), John A. Carver, and Ian F. Musgrave (University of Adelaide), unpublished data]. There is no evidence that milk itself contains cytotoxic amyloid fibrils and it would not be expected to contain such structures, given the strong and effective chaperone action of the naturally occurring mixture of different caseins. Indeed, caseins may be effective in reducing the cytotoxicity of fibrils formed by other proteins and hence could have therapeutic potential in the treatment of diseases associated with protein misfolding.

The chaperone activity of $\alpha_{S^{-}} \mathrm{CN}$ is higher at $\mathrm{pH} 7.0$ than in more alkaline solutions (Morgan et al., 2005). Intriguingly, the chaperone ability of $\alpha_{S^{-}} \mathrm{CN}$ is enhanced at lower temperatures and ionic strengths (Bettelheim et al., 1999; Morgan et al., 2005). The average size of $\alpha_{\mathrm{S} 1}-\mathrm{CN}$ oligomers increases with increasing ionic strength and temperature (Fox 2003). Self-assembly of caseins is thought to be driven primarily through the entropic interaction of P,Q-rich sequences (see the section on Quaternary Structures and the Hydrophobic Effect). Thus, as the chaperone activity of caseins is mediated through the same sequences, the self-association of $\alpha_{\mathrm{S}_{1}} \mathrm{CN}$ may reduce its ability to bind to and stabilize partially folded target proteins.

In preventing the heat-induced aggregation of catalase, $\alpha_{S^{-}}$and $\beta-C N$ form stable high-molecular-mass complexes with the enzyme (Morgan et al., 2005; Zhang et al., 2005). Like the sHsp, they show no refolding activity (Hassanisadi et al., 2008; Treweek et al., 2011). However, in contrast to sHsp, target proteins complexed to $\alpha_{S^{-}} \mathrm{CN}$ are not refolded by addition of Hsp70 and ATP (Treweek et al., 2011). This may be due, at least in part, to the target proteins being more tightly bound or buried in the complex with caseins than when interacting with sHsp. In the latter case, the target protein most likely coats the exterior of the sHsp oligomer (Regini et al., 2010). The tight binding of caseins to destabilized proteins is a property that could be utilized to develop them as a food stabilizing agent (see the Application to Food Science section).

The individual casein proteins differ in their relative chaperone abilities. For example, $\alpha_{\mathrm{S}^{-}} \mathrm{CN}$ is significantly better than $\beta-\mathrm{CN}$ at preventing the heat-induced aggregation of ovotransferrin (Matsudomi et al., 2004) or the reduction-induced aggregation of the insulin B-chain (Morgan et al., 2005). However, $\beta-\mathrm{CN}$ is more effective than $\alpha_{S^{-}} \mathrm{CN}$ at inhibiting the heat-induced aggregation of catalase and the reduction-induced aggregation of lysozyme (Zhang et al., 2005). Treweek et al. (2011) compared the chaperone ability of the individual $\alpha_{S^{-}}$ CN components, $\alpha_{\mathrm{S1}^{-}}$and $\alpha_{\mathrm{S}^{-}} \mathrm{CN}$, to prevent the amorphous or fibrillar aggregation of target proteins. Under heating and reduction stress, the chaperone abilities of $\alpha_{\mathrm{S}^{-}}$and $\alpha_{\mathrm{S}^{-}} \mathrm{CN}$ are similar and comparable to that of $\alpha_{S}-\mathrm{CN}$, whereas $\alpha_{\mathrm{S}^{-}} \mathrm{CN}$ is more effective than $\alpha_{\mathrm{S} 2}-\mathrm{CN}$ at inhibiting fibril formation by $\kappa-\mathrm{CN}$. Thorn et al. (2008) previously showed that $\alpha_{\mathrm{S} 1}-\mathrm{CN}$ is more effective than $\beta-\mathrm{CN}$ at inhibiting fibril formation by $\alpha_{\mathrm{S}^{2}} \mathrm{CN}$. Variation in the chaperone activities of the individual caseins is likely to depend on the target, the mode of aggregation (amorphous or fibrillar), and the buffer conditions, as has been observed for the sHsp $\alpha \mathrm{B}$-crystallin (Ecroyd et al., 2007; Ecroyd and Carver, 2008).

\section{CASEIN AMYLOID FIBRILS}

A causative role of amyloid fibrils (or their precursors) in human disease has been suspected for well over a century. Research concerning amyloid fibrils attracted considerable interest at the turn of the new millennium with the discovery that peptides and proteins not associated with amyloid-containing diseases; for example, the all- $\alpha$-helical protein myoglobin (Fandrich et al., 2001) can be coaxed into forming fibrils in vitro that are very similar to fibrils found in vivo. This finding, along with the observation that fibril-forming polypeptides vary widely in terms of their size, sequence, and native 3-dimensional fold, led to the proposal that the amyloid fibril was a conformation accessible to all polypeptides under the appropriate conditions (Fandrich et al., 2001; Dobson, 2003).

With this in mind, the capacity of milk proteins to form fibrils in vitro was investigated. Both $\alpha-\mathrm{LA}$ and $\beta$-LG form fibrils over a wide range of destabilizing conditions (Goers et al., 2002; Hamada and Dobson, 2002; Arnaudov et al., 2003; de Laureto et al., 2005). Similarly, BSA forms amyloid fibril-like structures at $85^{\circ} \mathrm{C}$ (Pearce et al., 2007). Clearly, this raises the possibility that the protein aggregates formed during many food processing operations are amyloid-like in character (see the Application to Food Science section). We and others have shown that 2 of the 4 bovine caseins, $\alpha_{S 2^{-}}$and $\kappa-\mathrm{CN}$, readily form fibrils in vitro (Farrell et al., 2003; Thorn et al., 2005, 2008). Crucially, and unlike other milk proteins, $\alpha_{\mathrm{S2}^{-}}$and $\kappa-\mathrm{CN}$ do so at physiological $\mathrm{pH}$ and temperature, an observation that has significant implications for mammary gland physiology and the biological role of caseins (see the Safe Secretion of High 
Concentrations of Potentially Fibrillogenic Casein Proteins section).

The propensity to form fibrils (Figure 2) under physiological conditions is a very common property of unfolded proteins, many of which (e.g., $\alpha$-synuclein, tau, amyloid $\beta$, and islet amyloid polypeptide) are associated with neurological disorders and age-onset diabetes (Uversky, 2008). For globular proteins, partial unfolding is a key step in the conversion to fibrils (Uversky and Fink, 2004), yet the fibrillogenic determinants of the resulting partially unfolded states are not properly defined. One proposal is that partially unfolded intermediates expose specific segments prone to forming intermolecular $\beta$-sheet interactions that are normally buried safely within stable, globular proteins. Indeed, Goldschmidt et al. (2010) showed, in a genome-wide survey, that almost all proteins contain at least one self-complementary, short sequence, called a steric zipper, that has the capability of forming a cross- $\beta$-sheet structure with interdigitated side chains (see Supplementary File, section S3.2; http://dx.doi. org/10.3168/jds.2013-6831). They also examined nonredundant protein structures in the Protein Data Bank (http://www.wwpdb.org/) to locate steric zippers in their 3 -dimensional structures. Only $0.6 \%$ were found to be on the surface, where they are potentially able to form specific intermolecular interactions and possibly fibrils. The majority were safely buried in the interior. The possibility of burying steric zipper sequences in the inaccessible interior of an unfolded protein does not exist. Moreover, zipper sequences are numerous in nearly all the caseins (Holt and Carver, 2012), particularly in the P,Q-rich sequences (Supplementary File, section S3.2 and Table S5; http://dx.doi.org/10.3168/jds.20136831). Clearly, an alternative means of avoiding fibril formation by caseins is necessary.

On their own (i.e., in the absence of other caseins), all 4 bovine caseins exhibit a propensity for self-association, forming a variety of oligomeric species. For example, reduced $\kappa$-CN forms roughly spherical 30-mers (Payens and Vreeman, 1982), with a hydrodynamic radius of 11 to $16 \mathrm{~nm}$ (Ossowski et al., 2012). These oligomers do

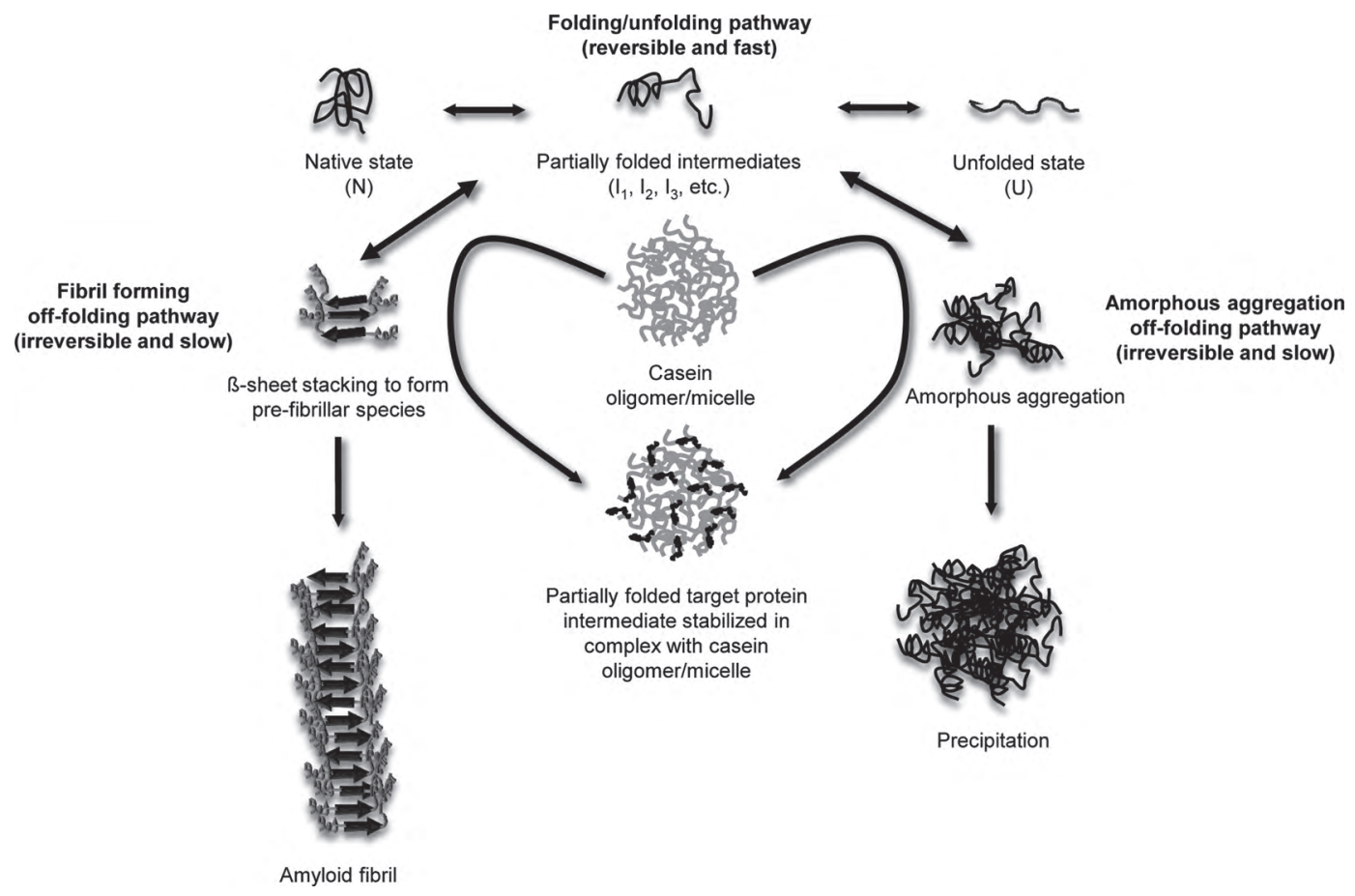

Figure 2. Schematic representation of the protein folding and unfolding and off-folding pathways and the interaction of casein oligomers or micelles to prevent target protein aggregation under stress conditions (Thorn et al., 2009). A native protein (N) unfolds via a variety of intermediate states $\left(I_{1}, I_{2}, \ldots\right)$ to the unfolded state $(\mathrm{U})$. This folding/unfolding pathway is fast and reversible, as indicated by the reversible arrows. However, if the intermediate states linger for too long (e.g., during times of cellular stress or due to mutation), they can self-associate via exposed hydrophobic regions that are normally buried in the native state of the protein. When self-association occurs, a partially folded intermediate enters an off-folding pathway which is slow and irreversible. The off-folding pathways form either an amorphous aggregate, leading to an amorphous insoluble protein precipitate, or a pathway forming a more ordered amyloid fibril having the cross $\beta$-sheet structure. A partially folded intermediate form of a target protein can interact with native casein micelles or oligomers of $\alpha_{S^{-}} \mathrm{CN}$ (a mixture of $\alpha_{\mathrm{S1}^{-}}$and $\left.\alpha_{\mathrm{S2}}{ }^{-} \mathrm{CN}\right)$ or $\beta$-CN at an early stage of either of the off-folding pathways to prevent it from self-associating. In doing so, the caseins form high-molecular-mass complexes with the target protein. The sizes of the casein oligomer/micelle and the structures formed in the folding/unfolding and off-folding pathways are not shown to scale in the figure. 
not have long-term stability, and solutions show a timedependent increase in mass, during which the association products become more fibrillar than spherical, with the eventual appearance of "rods" measuring 12 to 16 $\mathrm{nm}$ in diameter and, at $37^{\circ} \mathrm{C}$ or higher without stirring or at $25^{\circ} \mathrm{C}$ with stirring, up to several micrometers in length (Thorn et al., 2005; Léonil et al., 2008; Ossowski et al., 2012). Similarly, $\alpha_{S_{2}-}$ CN rapidly converts from spherical particles to form twisted ribbons up to $1 \mu \mathrm{m}$ in length when incubated at $37^{\circ} \mathrm{C}$ or higher (Thorn et al., 2008). Conditions under which $\alpha_{\mathrm{S}^{-}}$and $\beta-\mathrm{CN}$ form fibrils have not been reported.

The molecular mechanisms by which $\alpha_{\mathrm{S}^{-}}$and $\kappa-\mathrm{CN}$ form amyloid fibrils have not been elucidated in detail. It is worth noting, however, that native bovine $\alpha_{\mathrm{S}_{2}} \mathrm{CN}$ exists mostly as dimers formed by 2 intermolecular disulfide bridges (Rasmussen et al., 1999). In the case of native bovine $\kappa-\mathrm{CN}$, a series of disulfide-linked multimers (dimers to decamers or higher) exists (Rasmussen et al., 1999). These disulfide linkages largely dictate the oligomeric state of the precursor protein, which in turn is a critical determinant for fibril formation. With $\kappa-\mathrm{CN}$, the monomeric form has the highest propensity (Ecroyd et al., 2010), whereas $\alpha_{\mathrm{S}_{2}} \mathrm{CN}$ is most fibrillogenic in its disulfide-linked, dimeric form [D. C. Thorn, H. Ecroyd, M. Sunde (University of Sydney, Australia), and J. A. Carver, unpublished results]. Fibril formation by the disulfide-linked form of $\mathrm{\kappa}$ - $\mathrm{CN}$ found in micelles is therefore relatively limited at $37^{\circ} \mathrm{C}$, with the rate of formation increasing with incubation temperature and disulfide bond reduction (Thorn et al., 2005). However, oxidation of Met-95 and Met-106 of $\kappa-\mathrm{CN}$, both of which are outside the fibril-forming core, enhances fibril formation, as might occur under oxidative stress (Koudelka et al., 2012).

We and others have proposed that the bovine $\kappa-\mathrm{CN}$ fibril core is encompassed by the $\mathrm{Tyr}^{25}{ }^{25} \mathrm{Lys}^{86}$ region (Farrell et al., 2003; Ecroyd et al., 2008, 2010) because, upon fibril formation, this region is protected from limited proteolysis by the incorporation into, and thus burial of, at least part of this region in the $\beta$-sheet fibril core (Ecroyd et al., 2008). Examination of the AA sequence strongly supports this proposal: $\mathrm{Tyr}^{25}-\mathrm{Lys}^{86}$ is in the adhesive part of a P,Q-rich sequence derived from exon 4 (Supplementary Table S4; http://dx.doi. org/10.3168/jds.2013-6831). As noted in the Caseins as Unfolded Proteins section, P,Q-rich regions account for much of the association behavior of caseins. Moreover, Holt and Carver (2012) found that the segments $\mathrm{Val}^{48}-\mathrm{Phe}^{55}$ and $\mathrm{Ala}^{71}-\mathrm{Val}^{83}$ of bovine $\kappa_{-} \mathrm{CN}$ each contain one or more overlapping steric zipper sequences (see Supplementary File, section S3.2 and Table S4; http:// dx.doi.org/10.3168/jds.2013-6831; Goldschmidt et al.,
2010). The other 3 bovine caseins also have a number of zipper sequences (Holt and Carver, 2012). In $\alpha_{\mathrm{S} 2}-\mathrm{CN}, 2$ zipper sequences, $\mathrm{Asn}^{83}$-Try ${ }^{89}$ and $\mathrm{Gln}^{94}$-Leu ${ }^{99}$, are present within the central P,Q-rich portion of the protein, encoded by exon 11 (Kawasaki et al., 2011). Zipper sequences occur in the plasmin peptides $\mathrm{Ala}^{81}-\mathrm{Val}^{112}$, $\mathrm{Ala}^{81}-\mathrm{Lys}^{113}$, and $\mathrm{Ala}^{81}-\mathrm{Arg}^{125}$ from $\alpha_{\mathrm{S2}} \mathrm{CN}$, which have been isolated from mineralized, amyloid-like deposits (corpora amylacea) in bovine mammary tissue (Niewold et al., 1999). In $\alpha_{S 1^{-}}$and $\beta$-CN, zipper sequences may not be readily able to form complementary $\beta$-sheets because of competing nonspecific interactions with different sequences. Nevertheless, as discussed in Supplementary File, section S3.3 (http://dx.doi. org/10.3168/jds.2013-6831), some tryptic peptides from both of these caseins contain zipper sequences and are readily pelleted from the tryptic digest of whole casein by centrifugation, suggesting that they can form high-molecular-weight aggregates (Léonil et al., 1994) under certain conditions. It is not yet known whether the aggregates are fibrillar or amorphous.

\section{CASEIN MICELLE STRUCTURE}

Only the bovine casein micelle structure has been studied in detail. It is so easily perturbed by many of the usual methods of determining protein structure that very little can be concluded with certainty. Small-angle X-ray scattering (SAXS) provides the least perturbation because only dilution is required and this can be achieved with minimal environmental change by means of a milk ultrafiltrate or equilibrium diffusate. By this means, the activity of water, which is very important in entropic association processes, together with the free calcium, magnesium, and phosphate ion activities and the $\mathrm{pH}$, which control other aspects of casein micelle association through the sequestered ACP, are held very nearly constant. Small-angle neutron scattering (SANS) can also be measured after dilution but the diluent of choice is usually deuterium oxide rather than water and the scattering behavior is quite different to that seen by SAXS.

The SAXS data should therefore be given their due weight. Unfortunately, analysis of these data does not lead inexorably to a unique structure of the casein micelle without further information or assumptions. What can be obtained directly, without recourse to modelling, are the radius of gyration and the characteristic dimension(s) (scale) of the substructure. In the simplest version of the nanocluster model of casein micelle substructure (de Kruif and Holt, 2003; Holt et al., 2003), the composition, equilibrium radius, mass, and amorphous structure of the ACP core of casein- 
calcium phosphate nanoclusters successfully predicts the size and average spacing of denser substructures within the less dense protein matrix (Holt and Hukins, 1991; Holt et al., 2003). A thermodynamic model of the micelle has also been developed (Holt, 2004), which is based on the simplest nanocluster structural model (de Kruif and Holt, 2003; Holt et al., 2003). It predicts successfully, among other things, the partition of milk salts and the fraction of each of the caseins that is bound through one or more of its PC to the sequestered ACP. It also resolves the apparent paradox that the sequestered ACP is a basic salt in composition but an acidic salt according to its solubility behavior (Holt et al., 1989; Holt, 2004). An explicit expression for the equilibrium radius of the sequestered ACP nanoclusters has also been derived (Holt et al., 2009). More complex nanocluster models have been proposed that allow for a more inhomogeneous protein matrix (Bouchoux et al., 2009, 2010; de Kruif et al., 2012).

Electron and atomic force microscopy have produced many different images of casein micelles supporting both nanocluster and submicelle models. Careful comparisons of preparation techniques suggested that $2 \%$ glutaraldehyde fixation induces protein substructure (McMahon and McManus 1998; McMahon and Oommen, 2008, 2012). However, if micelles are not crosslinked, adsorbed micelles deform by flattening (Trejo et al., 2011; Ouanezar et al., 2012), which might itself induce or enlarge protein chain segregation to form lacunae. By contrast, crosslinking with transglutaminase appears not to affect casein micelle size or substructure, as measured by a range of scattering methods, and produces particles that are resistant to drastic changes in solvent quality (de Kruif et al., 2012). In protein submicellar models of casein micelle structure, the average separation of the dense substructures, about $18 \mathrm{~nm}$, has been interpreted as the diameter of the submicelles (Stothart and Cebula, 1982; Stothart, 1989; Hansen et al., 1996; Farrell et al., 2006a). Notwithstanding the many difficulties of sample preparation, a number of recent electron microscopical methods have yielded images of casein micelles that do not support any submicelle model but are consistent with nanocluster models (Holt et al., 1978; McMahon and McManus 1998; Marchin et al., 2007; Trejo et al., 2011).

The variability among species in the number of expressed casein genes and their relative proportions (Supplementary Table S1; http://dx.doi.org/10.3168/ jds.2013-6831), and differences in the architecture of the caseins, even among orthologs (Supplementary Table S2; http://dx.doi.org/10.3168/jds.2013-6831), suggest that there is much still to be learned about the structure and properties of nonbovine casein micelles.

\section{CASEIN MICELLE STRUCTURE AND ITS BIOLOGICAL FUNCTIONS}

The structure and biological functions of the casein micelle are intimately related. The 3 biological functions of the casein micelle considered here are (1) the safe secretion of high concentrations of calcium and phosphate so that the mammary gland does not become calcified, (2) the safe secretion of high concentrations of potentially fibrillogenic casein proteins through the mammary gland, and (3) retention of micelles in the stomach of the neonate so that nutrients can be digested and absorbed. Each function will be considered in relation to casein micelle structure.

The casein micelle should be considered a functional protein aggregate, distinct from aggregated species associated with physiological dysfunction and disease (Holt and Carver, 2012). Farrell et al. (2006b) noted that for the casein micelle to achieve its functions, a number of necessary types of interactions must be facilitated along the physiological pathway, whereas interactions favoring dysfunctional pathways; for example, those leading to the formation of fibrils or other amorphous structures, must be avoided. We propose that the interactions that predominate in both pathways may not be distinct. Indeed, casein association may be driven by a multitude of alternative and nearly equivalent interactions of low sequence specificity. For any given casein associating only with itself, the possibility of specific zipper sequences associating to form ordered fibrillar structures is at its highest, although competing nonspecific interactions may still occur. When the self-complementary interactions must compete with nonspecific interactions with a chaperone casein or a mixture of different caseins, then more amorphous aggregation is favored. This factor may go some way to explaining why casein micelles are always formed from a number of different caseins. The interdependence of caseins in ensuring the safe secretion of casein micelles is also exemplified by the fact that, while $\beta$ - and $\alpha_{\mathrm{S1}^{-}} \mathrm{CN}$ protect $\kappa$ - and $\alpha_{\mathrm{S}_{2}} \mathrm{CN}$ against self-aggregation leading to fibril formation, they, along with $\alpha_{\mathrm{S}_{2}}-\mathrm{CN}$, are themselves protected by $\kappa$-casein from calcium ion-induced precipitation.

Figure 3 depicts the functional pathway leading to casein micelles and 2 alternative dysfunctional protein association pathways leading to either an indefinitely large amorphous precipitate or ordered fibrillar structures. The prevention of dysfunctional fibrillogenesis by means of a limited, functional self-association or heteroassociation with binding partners is not uncommon in other biological contexts. Examples include transthyretin (Hurshman Babbes et al., 2008) and ataxin-3 (Masino et al., 2011), where fibrillogenic sequences become 


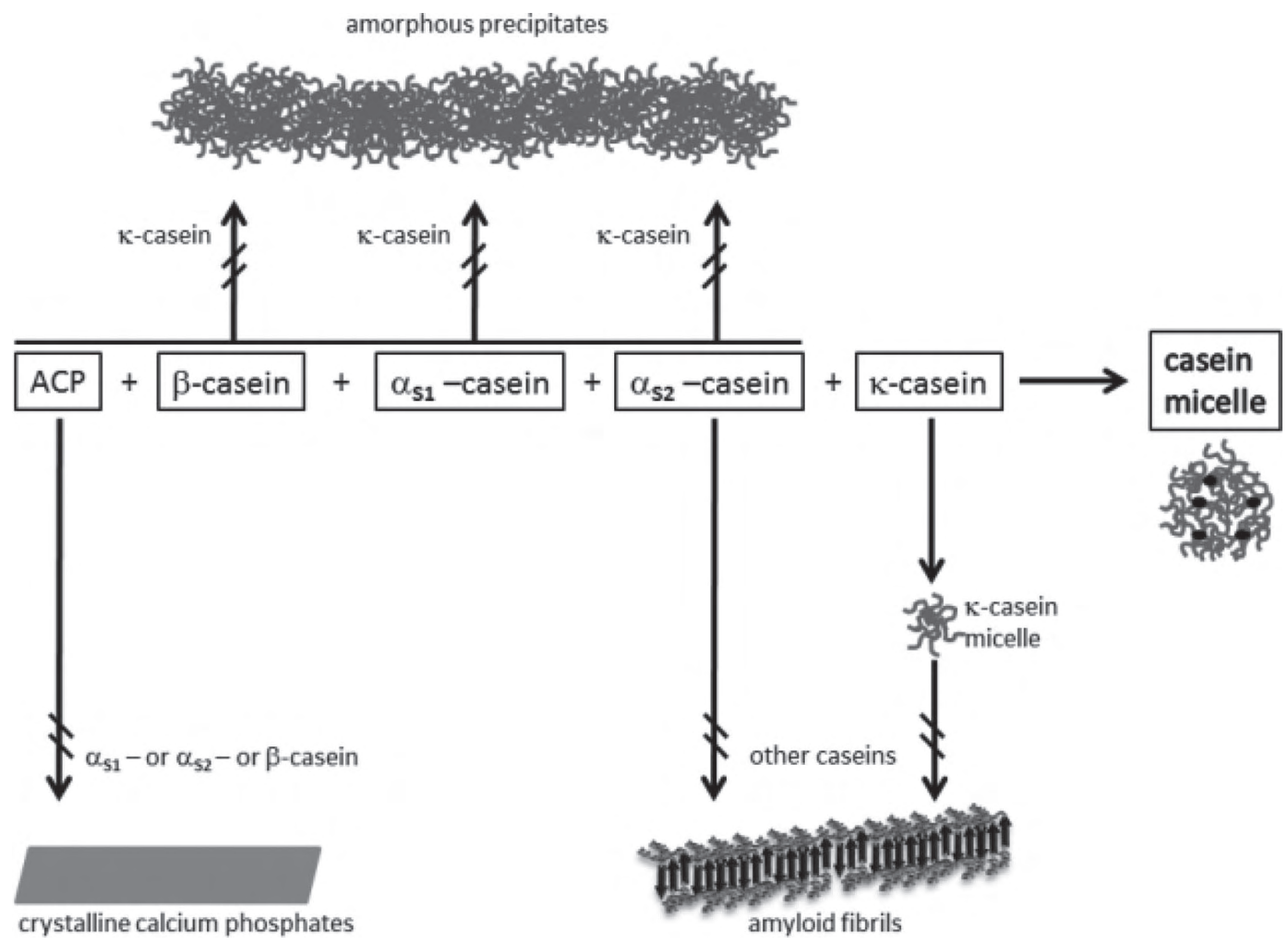

Figure 3. Functional and dysfunctional processes. The functional assembly of caseins and amorphous calcium phosphate (ACP) into the native bovine casein micelle is the central horizontal chemical equation. In the formation of casein micelles, nanoclusters of ACP are sequestered by the combined action of the calcium-sensitive $\alpha_{\mathrm{S1}^{-}}, \alpha_{\mathrm{S}^{-}}$, and $\beta$-CN to prevent the dysfunctional precipitation of calcium phosphate. The dysfunctional formation of amorphous casein precipitates of the calcium-sensitive caseins, either separately or together, is prevented by the chaperone-like action of $\kappa-\mathrm{CN}$. The dysfunctional formation of amyloid fibrils by the self-association of either $\alpha_{\mathrm{S2}^{-}}$or $\kappa$-CN is prevented by the chaperone action of all other caseins.

accessible only in the dissociated state. Figure 3 also shows the dysfunctional precipitation of calcium phosphate, which is prevented by the physiological process of sequestration by caseins.

\section{Safe Secretion of High Concentrations of Calcium and Phosphate}

Sequestration of ACP in bovine milk is accomplished by the calcium-sensitive caseins $\left(\alpha_{\mathrm{S} 1}, \alpha_{\mathrm{S} 2}\right.$, and $\beta$ ) and, by this means, dysfunctional ectopic deposits of calcium phosphate are prevented. There is a close similarity in salt and peptide composition, solubility, size, and structure between casein-calcium phosphate nanoclusters prepared in the laboratory with casein phosphopeptides and the sequestered ACP in native bovine casein micelles, strongly suggesting that most caseins are cemented into the micelle by links through their PC to an acidic ACP (Holt et al., 1989). The successful $a b$ initio calculation of the salt partition in bovine milk confirms the correctness of this assumption (Holt, 2004). On average, the calculations show that
10 to $20 \%$ of the $\beta-\mathrm{CN}$, but much less of the $\alpha_{\mathrm{S} 1^{-}}$and $\alpha_{\mathrm{S} 2}-\mathrm{CN}$, are held in the bovine micelle only by entropic effects, in semiquantitative agreement with micelle pelleting experiments that show an increase in "soluble" $\beta-\mathrm{CN}$ of up to $26 \%$ on cooling. Moreover, knowing the core mass of the ACP nanocluster prepared in the laboratory and the average of $7 \%$ calcium phosphate in micelles allows the average distance between the ACP nanoclusters, $\lambda$, to be calculated. The result, $\lambda=18.4$ $\mathrm{nm}$, provides a natural scale of chemical anisotropy in the casein micelle from which substructure can emerge (Holt et al., 2003).

\section{Safe Secretion of High Concentrations of Potentially Fibrillogenic Casein Proteins}

The exceptionally high casein concentration in the mammary alveolar lumina and repeated cycles of tissue remodeling are conditions that should favor fibril formation due to, for example, increased protease activity (Aslam and Hurley, 1997) and oxidative stress (Piantoni et al., 2010). As with other amyloidoses and dystrophic 
calcification diseases, the accumulation of amyloid fibrils and calcified deposits in mammary tissue has the potential to cause dysfunction; for example, by clogging small milk ducts. Nevertheless, deposits of amyloid and calcification are uncommon in the noncancerous mammary gland and, if present, seldom affect the efficiency of lactation. A mammary form of serum amyloid A, a protein deposited during systemic amyloidosis in a variety of tissues, has been identified (Jacobsen et al., 2005 ) and corpora amylacea containing casein peptides are formed in the mammary alveolar lumina during late lactation and involution (Nickerson et al., 1985).

The transition from a protolacteal fluid to nutritious milk began around 250 million years ago (Oftedal, 2012). Any increase, however, in the concentration of casein or calcium phosphate would have been accompanied, respectively, by an increased risk of amyloidosis and calcification. Holt and Carver (2012) proposed that both these potential problems were overcome by the co-secretion of ancestral $\beta$ - and $\kappa$ - $\mathrm{CN}$ to form a stable amorphous aggregate; that is, a primordial casein micelle. In this way, progressively more nutritious fluids could be produced by increasing the casein micelle concentration without endangering the reproductive potential of the mother. Further increases in casein and calcium phosphate concentration may have necessitated the diversification of ancestral $\beta-\mathrm{CN}$ into other calcium-sensitive caseins having an enhanced potential to either sequester calcium or stabilize other caseins prone to dysfunctional aggregation.

Unfolded proteins like the caseins can form many alternative and nearly equivalent intermolecular interactions, especially through adhesive P,Q-rich sequences of low charge density, while retaining their PP-II secondary structure. Tandem repeats in the P,Q-rich sequences help to provide alternative ways of interacting. The result is an open, hydrated, dynamic, and amorphous structure that competes effectively with pathways forming amyloid fibrils. Notwithstanding this, the affinity of amyloidophilic dyes such as Thioflavin $\mathrm{T}$ and Congo Red for casein micelles provides evidence of anhydrous cavities of a suitable size in the micelles into which the dyes can bind (Groenning et al., 2007a,b; Lencki, 2007). In amyloid fibrils, such cavities run parallel to the fibril axis between the elementary protofilaments. If casein micelles contain dye binding sites formed between short lengths of protofilaments, then amyloid-like interactions may play a part in maintaining their integrity.

However, on their own or in combination, calciumsensitive caseins can themselves precipitate at higher free calcium ion concentrations (Figure 3). On the other hand, bovine $\kappa-\mathrm{CN}$ does not sequester ACP, it is not precipitated by calcium ions, even at high concentrations
(Dickson and Perkins, 1971; Mekmene and Gaucheron, 2011, and it can stabilize the other calcium-sensitive caseins against precipitation by calcium ions (Waugh and Talbot, 1971). All milks contain an ortholog of $\kappa$-CN and, in the 6 examples where the composition of casein has been determined (Supplementary Table S1; http://dx.doi.org/10.3168/jds.2013-6831), the percentage of $\kappa$-CN in whole casein varies from less than $2 \%$ to more than 17\% (Baranyi et al., 1995; Miranda et al., 2004; Boumahrou et al., 2009; Holt and Carver, 2012). So vital is this stabilization for the proper formation and functioning of casein micelles that mice made deficient in $\kappa_{-}$CN fail to lactate (Shekar et al., 2006).

\section{Retention of Micelles in the Stomach of the Neonate so that Nutrients Can be Digested and Absorbed}

Caseins have a suboptimal composition in regard to some essential AA, particularly the sulfur-containing residue Met, probably because of structural requirements imposed by the other two functions that require an unfolded tertiary and nonfibrillar quaternary structure. Likewise, the open structure of the casein micelle can be considered a consequential property of the other two functions. Notwithstanding this, the open conformation permits access by proteinases to the entire primary structure and hence confers a nutritional benefit. An amorphous ACP is not needed to make the calcium bioavailable to the neonate because all calcium salts are fully soluble under acidic conditions but the amorphous phase is the only form of calcium phosphate that can be sequestered by phosphoproteins. Even though most aspects of the structure of casein micelles can be understood in terms of its nonnutritional biological functions, the susceptibility of the casein micelle to forming a rennet gel through the hydrolytic cleavage of the outer hairy layer or its ability to form an acid gel by reduction of the $\mathrm{pH}$, or more likely a combination of both, are best understood in terms of the nutritional needs of the neonate.

In the limited, initial proteolysis of bovine casein micelles by chymosin, the specific cleavage of the $\mathrm{Phe}^{105}$ Met ${ }^{106}$ peptide bond of $\kappa$-CN releases into solution the mucin-like phosphorylated and glycosylated macropeptide with a composition rich in hydroxy-amino acids (Supplementary Table S4; http://dx.doi.org/10.3168/ jds.2013-6831). This exposes the less hydrophilic, adhesive P,Q-rich sequences on the surface of the micelle, which can then form a gel by means of intermicellar interactions. In the acid gelation reaction, the calcium phosphate nanoclusters dissolve progressively as the $\mathrm{pH}$ decreases, allowing the released caseins to rearrange themselves to form a more extended network of interactions than was possible in the casein micelle. In 
other words, at or near the isoelectric point, the holdase chaperone action of the $\kappa-\mathrm{CN}$ is not enough to prevent the formation of indefinitely large casein structures.

\section{APPLICATION TO FOOD SCIENCE}

Caseins are unfolded SCPP with a tendency to form fibrils and act as molecular chaperones, and they have the ability to sequester ACP. In this section, these properties are considered in relation to some situations that occur in food processing. This brief and somewhat speculative treatment is for illustrative purposes only and is not intended to be a comprehensive review of food processing technology.

\section{Casein Chaperone Action and Fibril Formation in Food Processing}

The chaperone ability of caseins (Bhattacharyya and Das, 1999; Morgan et al., 2005) has potential widespread application in food processing; for example, in preventing undesirable precipitation of proteins and other components as a result of heat or pressure treatments. Indeed, this potential has been recognized by Yong and Foegeding (2010) in their review article summarizing the literature on casein chaperone action from 1999 to 2008. Although studies have investigated the in vitro chaperone action of caseins, none has systematically explored the applicability of casein chaperone action in stabilizing food components under stress conditions, particularly upon heating. As Yong and Foegeding (2010) conclude, "Much work is still needed to convert these primarily model system observations to practical applications for the food industry." Foegeding et al. (2010) expanded on this with their discussion on the possibility of utilizing the chaperone ability of caseins to alter the texture of foods; for example, to modify the density of a gel. There is a wealth of literature on the effects of temperature, $\mathrm{pH}$, salts, lipids, sugars, and so on, on casein protein structure and interactions. For example, casein chaperone action rationalizes the welldescribed phenomenon that, at 75 to $80^{\circ} \mathrm{C}$, whey proteins in milk partially unfold and interact with casein micelles to prevent whey protein precipitation or gel formation (summarized in Livney et al., 2003). Indeed, much of this literature, particularly under conditions of heating but also under pressure, should be reinterpreted and evaluated on the basis of the chaperone action of caseins.

For example, UHT treatment of milk can lead to irreversible gel formation during storage. Electron micrographs of casein micelles from aged UHT milk sometimes reveal protuberances, spikes, or tendrils comprising complexes of the whey protein $\beta-\mathrm{LG}$ and $\kappa-\mathrm{CN}$ (McMahon, 1996), particularly in gelled samples stored at $4^{\circ} \mathrm{C}$, where the tendrils often bridge between micelles. Casein micelle size also increases on storage, especially at room temperature or $37^{\circ} \mathrm{C}$ (Andrews et al., 1977). Various theories have been proposed to account for gelation, including proteolysis, physiochemical changes, and the aggregation of $\beta-\mathrm{LG}-\kappa-\mathrm{CN}$ complexes that form and subsequently dissociate from the casein micelle in UHT milk (McMahon 1996). The latter theory is consistent with the chaperone action of $\kappa-\mathrm{CN}$ to prevent the aggregation and precipitation of $\beta$-LG in UHT milk, the ability of $\kappa-\mathrm{CN}$ to form sheets or fibrils, possibly after dissociation from an oligomeric state such as a casein micelle (Farrell et al., 2003; Thorn et al., 2005; Ecroyd et al., 2008; Léonil et al., 2008), and the well-known phenomenon of gel formation by concentrated solutions of fibril-forming proteins (Guijarro et al., 1998). The transfer of $\kappa$-CN from the micelle into bridging fibrils might also contribute to the larger size of the micelles. A schematic illustration of the structural changes in casein micelles and $\beta$-LG during age-gelation of UHT milk is shown in Figure 4.

As discussed in the section on The Chaperone Action of Caseins, the chaperone ability of $\alpha_{S}-C N$ increases with decreasing temperature (Bhattacharyya and Das, 1999; Morgan et al., 2005). Potentially, this behavior could be utilized more generally in food processing to stabilize ingredients, particularly proteins, in frozen and cold foods to increase their storage and shelf life. In the dairy industry, the addition of $\alpha_{\mathrm{S}}$-CN to UHT milk could be used to prevent age gelation during lowtemperature storage. Furthermore, because the chaperone ability of $\alpha_{\mathrm{S}}$-CN to prevent the aggregation of $\beta-\mathrm{LG}$ at $70^{\circ} \mathrm{C}$ increases with decreasing $\mathrm{pH}$ (Morgan et al., 2005), it could be useful in stabilizing protein components in low-pH foods such as cheese and fruit juice.

The fibril-forming core region of $\kappa-\mathrm{CN}$ (residues $\mathrm{Tyr}^{25}$ to $\mathrm{Lys}^{86}$ ) is encompassed by the para- $\kappa-\mathrm{CN}$ peptide (residues 1 to 106) that is retained in the curd during cheese making (Ecroyd et al., 2008). The obvious question to ask, therefore, is whether the process of precipitation to form the curd involves fibril formation by para-k-CN. Attempts to answer this question have been hampered by the inherent insolubility of para- $\kappa-$ CN (Léonil et al., 2008). More work is warranted to explore the fibril-forming propensity of para- $\kappa-\mathrm{CN}$ and, more generally, to investigate whether the effects on the structure and other properties of milk products are associated with fibril formation by $\kappa$ - or para- $\kappa-\mathrm{CN}$. Another avenue to explore is the possibility that proteolysis of caseins in general leads to fibrillogenic peptide fragments. All 4 caseins contain sequences that are 


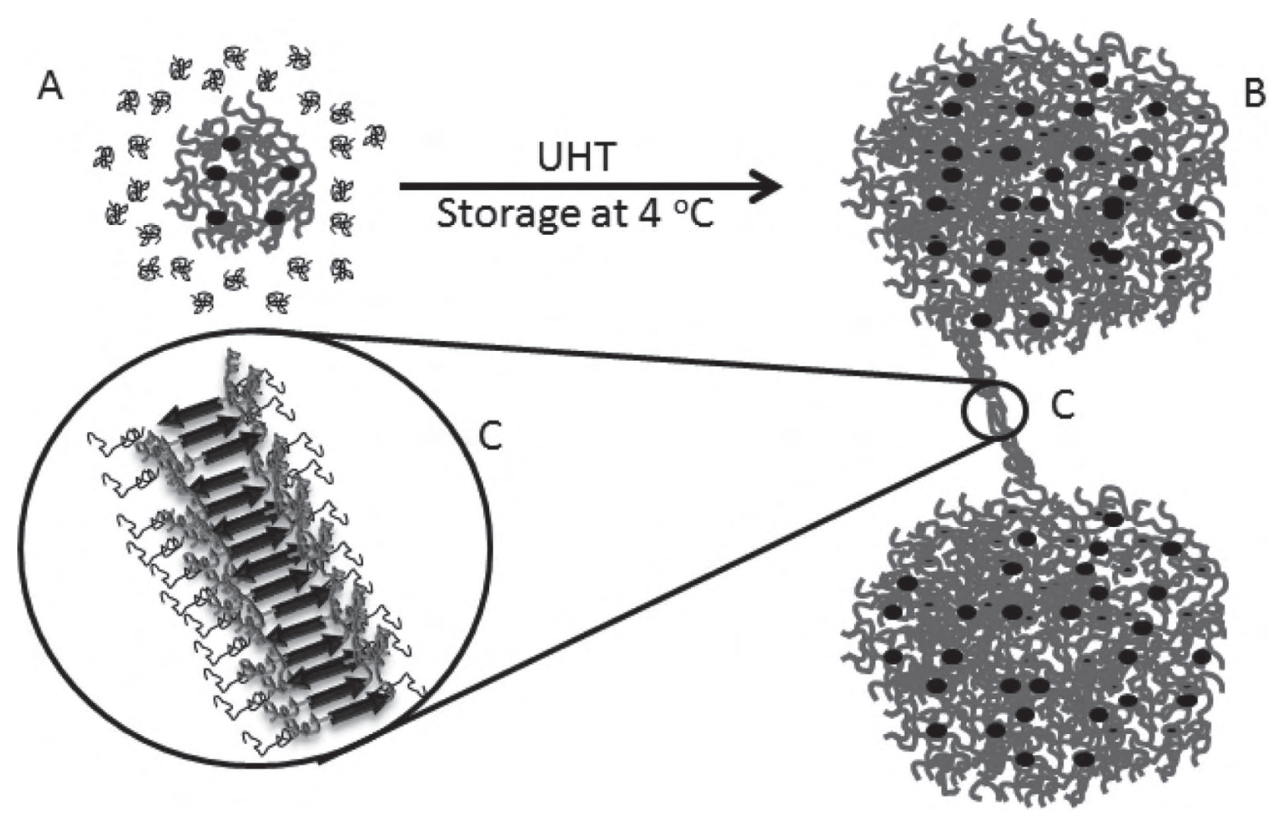

Figure 4. Structural changes in UHT milk in terms of the molecular chaperone and fibril-forming properties of $\kappa$-CN. (A) Native casein micelle containing nanoclusters of amorphous calcium phosphate in a continuous phase containing globular whey proteins; for example, $\beta$-LG. (B) Following UHT treatment and prolonged storage, casein micelle size increases and complexes of $\kappa$-casein and $\beta$-lactoglobulin dissociate from the micelle (Andrews et al., 1977). (C) A tendril comprising $\kappa-\mathrm{CN}$ and $\beta$-LG (McMahon, 1996) connecting 2 casein micelles. At higher magnification, the tendril is depicted as being formed from fibrillogenic $\kappa$ - $\mathrm{CN}$ sequences in a $\beta$-sheet conformation with the $\beta$-strands oriented perpendicular to the fibril axis. Decorating the fibril surface are partially folded $\beta-L G$ molecules.

predicted to form fibrils (Supplementary File, section S3.3; http://dx.doi.org/10.3168/jds.2013-6831; Holt and Carver, 2012). Thus, fibril formation by peptides derived from any casein may contribute to the properties of milk products that experience proteolysis during preparation or storage.

Different types of gels are formed when milk is subjected to high temperature or high pressure stress at low pH (summarized in Livney et al., 2003). Both treatments cause the whey proteins to partially unfold to adopt an intermediate state before gel formation but have different effects on casein micelle structure. Pressure treatments reduce the average size of casein micelles. Heat treatments usually have less effect but the dissociation of $\kappa$-CN occurs during heating and may not reverse fully on cooling. It is conceivable that a decrease in the chaperone ability of casein proteins occurs at high pressure (due to disruption of caseincasein interactions within the casein micelle) so that they cannot prevent the unfolding and gelation of whey proteins as efficiently. Compared with conventional techniques (e.g., heating), pressure treatment of milk may therefore provide different textures and other physical properties that could have use in the development of novel milk products such as yogurts with gellike textures (Gaucheron et al., 1997; Lopez-Fandino et al., 1997).

\section{Shear Stress and Casein Protein Aggregation}

Processing of milk via homogenization forces the liquid at high speed and pressure (typically $5.5 \mathrm{~L} / \mathrm{s}$ at $14 \mathrm{MPa}$ ) through a small orifice. As a result, fat globules are broken up and the milk becomes homogeneous. During homogenization, the milk components undergo considerable shear stress. Similar shear stress occurs under bioprocessing events such as pumping, fractionation, and ultrafiltration of milk. For the constituent milk proteins, shear has the potential to cause conformational changes, in particular unfolding. Indeed, it has been recognized from a series of studies on a diversity of proteins that shear can cause unfolding of polypeptide chains to varying degrees (reviewed in Bekard et al., 2011).

In the case of amyloid fibril-forming proteins, it is well known that aggregation occurs faster and to a greater extent upon agitation; for example, by shaking or stirring. Indeed, this is a common method to induce and enhance the rate of fibril formation of proteins in vitro. Furthermore, processes that cause fragmentation of preformed fibrils (e.g., sonication) also prompt fibril growth (Knowles et al., 2007). Dunstan and colleagues have investigated the effects of shear flow on fibril formation by a variety of proteins, including $\beta$-LG, which forms fibrils at low pH and high temperature (e.g., Hill 
et al., 2006; Hamilton-Brown et al., 2008; Dunstan et al., 2009; Teoh et al., 2011). From these studies, it was concluded that shear promotes fibril formation and affects fibril morphology. The shear force placed on the protein leads to partial unfolding, facilitation of oligomerization, and the formation of protofibrils, the species that are prerequisites to mature amyloid fibrils. It is conceivable that similar behavior will occur for $\kappa-$ and $\alpha_{\mathrm{S}^{2}} \mathrm{CN}$ during homogenization and bioprocessing events, particularly if shear disrupts the integrity of the casein micelle and causes the intimate association of the casein proteins within the micelle (e.g., the stabilizing interaction between $\alpha_{\mathrm{S}^{-}}$and $\alpha_{\mathrm{S}^{2}} \mathrm{CN}$ ) to be compromised. The effects of shear stress on individual caseins, their mixtures, and the casein micelle have not been determined but may provide significant insight into the effects of homogenization and bioprocessing on the morphology and interactions of caseins, and the properties of milk and processed milk products.

\section{Environmental Effects on the Partition of Milk Salts}

The equilibria among the milk salts exert a profound influence on milk processing behavior (reviewed in Holt 1985, 1997; Gaucheron, 2004; Lucey and Horne, 2012). Two distinct effects can be discerned, even though they are usually confounded. On the one hand are electrostatic effects due to net protein charge determined by $\mathrm{pH}$ and the binding of ions, principally $\mathrm{Ca}^{2+}$ and $\mathrm{Mg}^{2+}$. On the other hand is the effect of a change in salt partition that determines, among other things, the partition of individual caseins between the micelle and the continuous phase. It is noteworthy that the molecular chaperone and fibrillogenic properties of caseins in the continuous phase are expected to be much more apparent than when they are associated in the micelle.

A useful tool for understanding the behavior of milk salts under different solution conditions is a computer program that models the ion equilibria and their interactions with other milk components, principally caseins (Holt, 2004). A commercially available program uses a more empirical approach without explicitly allowing for the protein equilibria (Mekmene et al., 2009, 2010). The principal environmental factors affecting these equilibria are temperature, pressure, $\mathrm{pH}$, and ionic strength, and these can produce effects that are reversible, slow to reverse, or effectively irreversible. Equilibrium phenomena require that (1) there be a stoichiometric excess of PC over the ACP generated by an environmental change, (2) the starting milk is at equilibrium, and (3) the environmental change be applied gradually.

There is usually a stoichiometric excess of PC in milk from cows in early or mid lactation but the frequency of metastable milks increases with stage of lactation and mastitis (Holt, 2004). A metastable milk contains some proportion of sequestered ACP in an unstable form which can, for example, be converted to a more crystalline phase such as hydroxyapatite by heating (Cross et al., 2005). Increasing the $\mathrm{pH}$ of milk can make it metastable and if a strong base is used, the locally high $\mathrm{pH}$ can generate ACP, which matures into a more stable phase before it can be sequestered to form equilibrium nanocomplexes. Other irreversible or slow-to-reverse phenomena are acid coagulation of proteins following the addition of strong acids and pressure-induced dissociation of caseins from micelles. The profound reduction in the size of micelles produced by high pressure treatments is accompanied by an apparent increase in "soluble" casein, calcium, and inorganic phosphate, as determined by pelleting experiments. Careful ultrafiltration experiments (Regnault et al., 2006) have shown, however, that the "soluble" components are still complexed together but are obviously not as easily pelleted by a given centrifugation procedure.

Heat treatment of milk generally produces reversible effects on the salt partition when allowance is made for $\mathrm{pH}$ change and sufficient time is allowed for reequilibration (Pouliot et al., 1989a,b; On-Nom et al., 2010). However, mineral-rich deposits build up over time on heated surfaces during milk processing operations such as heat sterilization. The explanation may be that casein micelles are excluded from the surface by denatured serum proteins but the aqueous phase is not. Hence, the micelles cannot sequester further nuclei of $\mathrm{ACP}$ as they form next to the heating element.

\section{SUMMARY AND CONCLUSIONS}

The casein micelle provides solutions to physiological risks of amyloidosis and pathological calcification while providing the neonate with adequate nutrition through the ability of the micelles to form gels by acidification, proteolysis, or both. These same properties are evident in dairy processing or food applications. Caseins released from the micelle by changes in their physiological environment behave very differently from the micelles themselves. Thus, individual caseins or fragments thereof can act as molecular chaperones or as fibril-forming agents. The extent to which the calcium-sensitive caseins can be released from the micelle depends on the partition of milk salts, $\mathrm{pH}$, and temperature. In a broader context, these properties provide opportunities for novel applications in food processing and as food additives. Although there is no evidence of amyloid fibrils in milk, we have speculated that fibrils may form in certain dairy products. If tested and proved correct, then further research to 
minimize the fibril content of dairy products may be advisable (Greger, 2008).

\section{ACKNOWLEDGMENTS}

We thank Lindsay Sawyer (Edinburgh University, Edinburgh, UK), Tommy Nylander (Lund University, Lund, Sweden), Joëlle Léonil (INRA, Rennes, France), Federico M. Harte (University of Tennessee, Knoxville), and Donald J. McMahon (Utah State University, Logan) for useful discussions during the writing of this review and Sarah Meehan (University of Cambridge, UK), Margaret Sunde (University of Sydney, Australia), Tomas Koudelka, Ian F. Musgrave, and Kegomoditswe Regoeng (all from University of Adelaide, Australia), and Phillip Morgan, Teresa Treweek, and William Price (all from University of Wollongong, Australia) for their considerable contributions to aspects of our casein research.

\section{REFERENCES}

Aichmayer, B., H. C. Margolis, R. Sigel, Y. Yamakoshi, J. P. Simmer, and P. Fratzl. 2005. The onset of amelogenin nanosphere aggregation studied by small-angle X-ray scattering and dynamic light scattering. J. Struct. Biol. 151:239-249. http://dx.doi. org/10.1016/j.jsb.2005.06.007.

Andrews, A. T., B. E. Brooker, and D. G. Hobbs. 1977. Properties of aseptically packed ultra-heat-treated milk: Electron microscopic examination of changes occurring during storage. J. Dairy Res. 44:283-292.

Arnaudov, L. N., R. de Vries, H. Ippel, and C. P. M. van Mierlo. 2003. Multiple steps during the formation of $\beta$-lactoglobulin fibrils. Biomacromolecules 4:1614-1622. http://dx.doi.org/10.1021/ bm034096b.

Arunachalam, J., and N. Gautham. 2008. Hydrophobic clusters in protein structures. Proteins 71:2012-2025. http://dx.doi. org/10.1002/prot.21881.

Aslam, M., and W. L. Hurley. 1997. Proteolysis of milk proteins during involution of the bovine mammary gland. J. Dairy Sci. 80:20042010.

Baldwin, R. L., and B. H. Zimm. 2000. Are denatured proteins ever random coils? Proc. Natl. Acad. Sci. USA 97:12391-12392. http://dx.doi.org/10.1073/pnas.97.23.12391.

Baranyi, M., G. Brignon, P. Anglade, and B. Ribadeau-Dumas. 1995. New data on the proteins of rabbit (Oryctolagus cuniculus) milk. Comp. Biochem. Physiol. B 111:407-415.

Barral, J. M., S. A. Broadley, G. Schaffar, and F. U. Hartl. 2004 Roles of molecular chaperones in protein misfolding diseases. Semin. Cell Dev. Biol. 15:17-29. http://dx.doi.org/10.1016/j. semcdb.2003.12.010.

Bekard, I. B., P. Asimakis, J. Bertolini, and D. E. Dunstan. 2011. The effects of shear flow on protein structure and function. Biopolymers 95:733-745. http://dx.doi.org/10.1002/bip.21646.

Bettelheim, F. A., R. Ansari, Q. F. Cheng, and J. S. Zigler. 1999. The mode of chaperoning of dithiothreitol-denatured $\alpha$-lactalbumin by $\alpha$-crystallin. Biochem. Biophys. Res. Commun. 261:292-297. http://dx.doi.org/10.1006/bbrc.1999.1031

Bhattacharyya, J., and K. P. Das. 1999. Molecular chaperone-like properties of an unfolded protein, $\alpha_{S}$-casein. J. Biol. Chem. 274:15505-15509.

Bigelow, C. C. 1967. On the average hydrophobicity of proteins and relation between it and protein structure. J. Theor. Biol. 16:187211.
Bouchoux, A., P. E. Cayemitte, J. Jardin, G. Gesan-Guiziou, and B. Cabane. 2009. Casein micelle dispersions under osmotic stress. Biophys. J. 96:693-706. http://dx.doi.org/10.1016/j.bpj.2008.10.006.

Bouchoux, A., G. Gesan-Guiziou, J. Perez, and B. Cabane. 2010. How to squeeze a sponge: Casein micelles under osmotic stress, a SAXS study. Biophys. J. 99:3754-3762. http://dx.doi.org/10.1016/j. bpj.2010.10.019.

Boumahrou, N., S. Andrei, G. Miranda, C. Henry, J. J. Panthier, P. Martin, and S. Bellier. 2009. The major protein fraction of mouse milk revisited using proven proteomic tools. J. Physiol. Pharmacol. 60:113-118.

Buchko, G. W., B. J. Tarasevich, J. Bekhazi, M. L. Snead, and W. J. Shaw. 2008. A solution NMR investigation into the early events of amelogenin nanosphere self-assembly initiated with sodium chloride or calcium chloride. Biochemistry 47:13215-13222. http:// dx.doi.org/10.1021/bi8018288.

Carrotta, R., C. Canale, A. Diaspro, A. Trapani, P. L. San Biagio, and D. Bulone. 2012. Inhibiting effect of $\alpha_{\mathrm{S} 1}$-casein on $A \beta_{1-40}$ fibrillogenesis. Biochim. Biophys. Acta 1820:124-132. http://dx.doi. org/10.1016/j.bbagen.2011.11.010.

Carver, J. A., A. Rekas, D. C. Thorn, and M. R. Wilson. 2003. Small heat-shock proteins and clusterin: Intra- and extracellular molecular chaperones with a common mechanism of action and function? IUBMB Life 55:661-668. http://dx.doi.org/10.1080/1521654031 0001640498 .

Cooper, A. 2000. Heat capacity of hydrogen-bonded networks: An alternative view of protein folding thermodynamics. Biophys. Chem. 85:25-39.

Cooper, A. 2005. Heat capacity effects in protein folding and ligand binding: A re-evaluation of the role of water in biomolecular thermodynamics. Biophys. Chem. 115:89-97. http://dx.doi. org/10.1016/j.bpc.2004.12.011.

Cross, K. J., N. L. Huq, J. E. Palamara, J. W. Perich, and E. C. Reynolds. 2005. Physicochemical characterization of casein phosphopeptide-amorphous calcium phosphate nanocomplexes. J Biol. Chem. 280:15362-15369. http://dx.doi.org/10.1074/jbc. M413504200.

Cubellis, M. V., F. Caillez, T. L. Blundell, and S. C. Lovell. 2005. Properties of polyproline II, a secondary structure element implicated in protein-protein interactions. Proteins 58:880-892. http://dx.doi.org/10.1002/prot.20327.

Dalgleish, D. G. 2011. On the structural models of bovine casein micelles-Review and possible improvements. Soft Matter 7:22652272. http://dx.doi.org/10.1039/c0sm00806k.

Dalgleish. D. G.. and M. Corredig. 2012. The structure of the casein micelle of milk and its changes during processing. Ann. Rev. Food Sci. Technol. 3:449-467. http://dx.doi.org/10.1146/annurevfood-022811-101214

Dalgleish, D. G., H. D. Goff, and B. B. Luan. 2002. Exchange reactions between whey proteins and caseins in heated soya oil-in-water emulsion systems-Behavior of individual proteins. Food Hydrocoll. 16:295-302. http://dx.doi.org/10.1016/s0268-005x(01)00102-3.

de Kruif, C. G., and C. Holt. 2003. Casein micelle structure, functions and interactions. Pages 233-276 in Advanced Dairy Chemistry. Vol. 1A: Proteins: Basic Aspects. 3rd ed. P. F. Fox and P. L. H. McSweeney, ed. Kluwer, New York, NY.

de Kruif, C. G., T. Huppertz, V. S. Urban, and A. V. Petukhov. 2012 Casein micelles and their internal structure. Adv. Colloid Interface Sci. 171-172:36-52. http://dx.doi.org/10.1016/j.cis.2012.01.002.

de Laureto, P. P., E. Frare, F. Battaglia, M. F. Mossuto, V. N. Uversky, and A. Fontana. 2005. Protein dissection enhances the amyloidogenic properties of $\alpha$-lactalbumin. FEBS J. 272:2176-2188. http://dx.doi.org/10.1111/j.1742-4658.2005.04638.x.

Dehle, F. C., H. Ecroyd, I. F. Musgrave, and J. A. Carver. 2010. $\alpha B$-Crystallin inhibits the cell toxicity associated with amyloid fibril formation by $\kappa$-casein and the amyloid- $\beta$ peptide. Cell Stress Chaperones 15:1013-1026. http://dx.doi.org/10.1007/s12192-0100212-z.

Delak, K., C. Harcup, R. Lakshminarayanan, Z. Sun, Y. Fan, J. Moradian-Oldak, and J. S. Evans. 2009. The tooth enamel protein, porcine amelogenin, is an intrinsically disordered protein with an 
extended molecular configuration in the monomeric form. Biochemistry 48:2272-2281. http://dx.doi.org/10.1021/bi802175a.

Dickson, I. R., and D. J. Perkins. 1971. Studies on interactions between purified bovine caseins and alkaline-earth metal ions. Biochem. J. 124:235-240.

Djikaev, Y. S., and E. Ruckenstein. 2009. Effect of hydrogen bond networks on the nucleation mechanism of protein folding. Phys. Rev. E Stat. Nonlin. Soft Matter Phys. 80:061918. http://dx.doi. org/10.1103/PhysRevE.80.061918.

Dobson, C. M. 1999. Protein misfolding, evolution and disease. Trends Biochem. Sci. 24:329-332. http://dx.doi.org/10.1016/ s0968-0004(99)01445-0.

Dobson, C. M. 2003. Protein folding and misfolding. Nature 426:884890. http://dx.doi.org/10.1038/nature02261.

Dunstan, D. E., P. Hamilton-Brown, P. Asimakis, W. Ducker, and J. Bertolini. 2009. Shear-induced structure and mechanics of B-lactoglobulin amyloid fibrils. Soft Matter 5:5020-5028. http:// dx.doi.org/10.1039/b914089a.

Ecroyd, H., and J. A. Carver. 2008. The effect of small molecules in modulating the chaperone activity of $\alpha$-B-crystallin against ordered and disordered protein aggregation. FEBS J. 275:935-947. http://dx.doi.org/10.1111/j.1742-4658.2008.06257.x.

Ecroyd, H., and J. A. Carver. 2009. Crystallin proteins and amyloid fibrils. Cell. Mol. Life Sci. 66:62-81. http://dx.doi.org/10.1007/ s00018-008-8327-4.

Ecroyd, H., T. Koudelka, D. C. Thorn, D. M. Williams, G. Devlin, P. Hoffmann, and J. A. Carver. 2008. Dissociation from the oligomeric state is the rate-limiting step in fibril formation by $\kappa$-casein. J. Biol. Chem. 283:9012-9022. http://dx.doi.org/10.1074/jbc. M709928200.

Ecroyd, H., S. Meehan, J. Horwitz, J. A. Aquilina, J. L. P. Benesch, C. V. Robinson, C. E. Macphee, and J. A. Carver. 2007. Mimicking phosphorylation of $\alpha \mathrm{B}$-crystallin affects its chaperone activity. Biochem. J. 401:129-141. http://dx.doi.org/10.1042/BJ20060981.

Ecroyd, H., D. C. Thorn, Y. Liu, and J. A. Carver. 2010. The dissociated form of $\kappa$-casein is the precursor to its amyloid fibril formation. Biochem. J. 429:251-260. http://dx.doi.org/10.1042/ BJ20091949.

Fandrich, M., M. A. Fletcher, and C. M. Dobson. 2001. Amyloid fibrils from muscle myoglobin-Even an ordinary globular protein can assume a rogue guise if conditions are right. Nature 410:165-166.

Farrell, H. M., P. H. Cooke, E. D. Wickham, E. G. Piotrowski, and P. D. Hoagland. 2003. Environmental influences on bovine k-casein: Reduction and conversion to fibrillar amyloid structures. J. Protein Chem. 22:259-273.

Farrell, H. M., R. Jimenez-Flores, G. T. Bleck, E. M. Brown, J. E. Butler, L. K. Creamer, C. L. Hicks, C. M. Hollar, K. F. Ng-KwaiHang, and H. E. Swaisgood. 2004. Nomenclature of the proteins of cows' milk - Sixth revision. J. Dairy Sci. 87:1641-1674.

Farrell, H. M., E. L. Malin, E. M. Brown, and P. X. Qi. 2006a. Casein micelle structure: What can be learned from milk synthesis and structural biology? Curr. Opin. Colloid Interface Sci. 11:135-147. http://dx.doi.org/10.1016/j.cocis.2005.11.005

Farrell, H. M., P. X. Qi, and V. N. Uversky. 2006b. New views of protein structure: Applications to the caseins: Protein structure and functionality. Pages 52-70 in Advances in Biopolymers. Vol. 935. M. L. Q. Fishman, P. X. Qi, and L. Wicker ed. ACS Symposium Series. American Chemical Society, Columbus, $\mathrm{OH}$.

Fincham, A.G., J. Moradian-Oldak, and J. P. Simmer. 1999. The structural biology of the developing dental enamel matrix. J. Struct. Biol. 126:270-299.

Fisher, L. W., D. A. Torchia, B. Fohr, M. F. Young, and N. S. Fedarko. 2001. Flexible structures of SIBLING proteins, bone sialoprotein, and osteopontin. Biochem. Biophys. Res. Commun. 280:460-465.

Foegeding, E. A., E. Cakir, and H. Koc. 2010. Using dairy ingredients to alter texture of foods: Implications based on oral processing considerations. Int. Dairy J. 20:562-570. http://dx.doi. org/10.1016/j.idairyj.2009.12.013.

Fox, P. F. 2003. Milk proteins: General and historical aspects. Pages 1-48 in Advanced Dairy Chemistry. Vol. 1A: Proteins: Basic As- pects. 3rd ed. P. F. Fox and P. L. H. McSweeney, ed. Springer, New York, NY.

Fox, P. F., and A. Brodkorb. 2008. The casein micelle: Historical aspects, current concepts and significance. Int. Dairy J. 18:677-684. http://dx.doi.org/10.1016/j.idairyj.2008.03.002.

Gaucheron, F. 2004. Minéraux et Produits Laitiers. Tec \& Doc Paris, Paris, France.

Gaucheron, F., M. H. Famelart, F. Mariette, K. Raulot, F. Michel, and Y. Le Graet. 1997. Combined effects of temperature and highpressure treatments on physicochemical characteristics of skim milk. Food Chem. 59:439-447. http://dx.doi.org/10.1016/s03088146(96)00301-9.

Goers, J., S. E. Permyakov, E. A. Permyakov, V. N. Uversky, and A. L. Fink. 2002. Conformational prerequisites for $\alpha$-lactalbumin fibrillation. Biochemistry 41:12546-12551. http://dx.doi.org/10.1021/ bi0262698.

Goldschmidt, L., P. K. Teng, R. Riek, and D. Eisenberg. 2010. Identifying the amylome, proteins capable of forming amyloid-like fibrils. Proc. Natl. Acad. Sci. USA 107:3487-3492. http://dx.doi. org/10.1073/pnas.0915166107.

Greger, M. 2008. Amyloid fibrils: Potential food safety implications. Int. J. Food Safety Nutr. Public Health 1:103-115. http://dx.doi. org/10.1504/ijfsnph.2008.023011.

Groenning, M., M. Norrman, J. M. Flink, M. van de Weert, J. T. Bukrinsky, G. Schluckebier, and S. Frokjaer. 2007a. Binding mode of Thioflavin T in insulin amyloid fibrils. J. Struct. Biol. 159:483497. http://dx.doi.org/10.1016/j.jsb.2007.06.004.

Groenning, M., L. Olsen, M. van de Weert, J. M. Flink, S. Frokjaer, and F. S. Jorgensen. 2007b. Study on the binding of Thioflavin T to $\beta$-sheet-rich and non- $\beta$-sheet cavities. J. Struct. Biol. 158:358 369. http://dx.doi.org/10.1016/j.jsb.2006.12.010.

Gu, W., M. Kofler, I. Antes, C. Freund, and V. Helms. 2005. Alternative binding modes of proline-rich peptides binding to the GYF domain. Biochemistry 44:6404-6415. http://dx.doi.org/10.1021/ bi0479914.

Guha, S., T. K. Manna, K. P. Das, and B. Bhattacharyya. 1998. Chaperone-like activity of tubulin. J. Biol. Chem. 273:30077-30080. http://dx.doi.org/10.1074/jbc.273.46.30077.

Guijarro, J. I., M. Sunde, J. A. Jones, I. D. Campbell, and C. M. Dobson. 1998. Amyloid fibril formation by an SH3 domain. Proc. Natl. Acad. Sci. USA 95:4224-4228. http://dx.doi.org/10.1073/ pnas.95.8.4224.

Hamada, D., and C. M. Dobson. 2002. A kinetic study of $\beta$-lactoglobulin amyloid fibril formation promoted by urea. Protein Sci. 11:24172426. http://dx.doi.org/10.1110/ps.0217702.

Hamilton-Brown, P., I. Bekard, W. A. Ducker, and D. E. Dunstan. 2008. How does shear affect A $\beta$ fibrillogenesis? J. Phys. Chem. B 112:16249-16252. http://dx.doi.org/10.1021/jp805257n.

Hanazono, Y., K. Takeda, M. Yohda, and K. Miki. 2012. Structural studies on the oligomeric transition of a small heat shock protein, StHsp14.0. J. Mol. Biol. 422:100-108. http://dx.doi. org/10.1016/j.jmb.2012.05.017.

Hansen, S., R. Bauer, S. B. Lomholt, K. B. Quist, J. S. Pedersen, and K. Mortensen. 1996. Structure of casein micelles studied by smallangle neutron scattering. Eur. Biophys. J. 24:143-147.

Harper, J. D., and P. T. Lansbury. 1997. Models of amyloid seeding in Alzheimier's disease and scrapie: Mechanistic truths and physiological consequences of the time-dependent solubility of amyloid proteins. Annu. Rev. Biochem. 66:385-407.

Hartl, F. U., A. Bracher, and M. Hayer-Hartl. 2011. Molecular chaperones in protein folding and proteostasis. Nature 475:324-332. http://dx.doi.org/10.1038/nature10317.

Haslbeck, M., T. Franzmann, D. Weinfurtner, and J. Buchner. 2005. Some like it hot: The structure and function of small heat-shock proteins. Nat. Struct. Mol. Biol. 12:842-846. http://dx.doi. org $/ 10.1038 /$ nsmb993.

Hassanisadi, M., A. Barzear, R. Yousefi, M. Dalgalarrondo, J.-M. Chobert, T. Haertle, A. A. Saboury, and A. A. Moosaui-Mouahedi. 2008. Chemometric study of the aggregation of alcohol dehydrogenase and its suppression by $\beta$-caseins: A mechanistic perspec- 
tive. Anal. Chim. Acta 613:40-47. http://dx.doi.org/10.1016/j. aca.2008.02.036.

Hicks, J. M., and V. L. Hsu. 2004. The extended left-handed helix: A simple nucleic acid-binding motif. Proteins 55:330-338. http:// dx.doi.org/10.1002/prot.10630.

Hill, E. K., B. Krebs, D. G. Goodall, G. J. Howlett, and D. E. Dunstan. 2006. Shear flow induces amyloid fibril formation. Biomacromolecules 7:10-13. http://dx.doi.org/10.1021/bm0505078.

Holt, C. 1985. The milk salts: Their secretion, concentrations and physical chemistry. Pages 143-181 in Developments in Dairy Chemistry. Vol. 3: Lactose and Minor Constituents. P. F. Fox, ed. Elsevier Applied Science, London, UK.

Holt, C. 1997. The milk salts and their interaction with casein. Pages 233-254 in Advanced Dairy Chemistry. Vol. 3: Lactose, Water, Salts, and Vitamins. 2nd ed. P. F. Fox, ed. Chapman and Hall, London, UK.

Holt, C. 1998. Casein micelle substructure and calcium phosphate interactions studied by sephacryl column chromatography. J. Dairy Sci. 81:2994-3003.

Holt, C. 2004. An equilibrium thermodynamic model of the sequestration of calcium phosphate by casein micelles and its application to the calculation of the partition of salts in milk. Eur. Biophys. J. 33:421-434. http://dx.doi.org/10.1007/s00249-003-0377-9.

Holt, C. 2013. Unfolded phosphopolypeptides enable soft and hard tissues to coexist in the same organism with relative ease. Curr. Opin. Struct. Biol. 23:420-425. http://dx.doi.org/10.1016/j. sbi.2013.02.010.

Holt, C., and J. A. Carver. 2012. Darwinian transformation of a 'scarcely nutritious fluid' into milk. J. Evol. Biol. 25:1253-1263. http://dx.doi.org/10.1111/j.1420-9101.2012.02509.x.

Holt, C., C. G. de Kruif, R. Tuinier, and P. A. Timmins. 2003. Substructure of bovine casein micelles by small-angle X-ray and neutron scattering. Colloids Surf. A Physicochem. Eng. Asp. 213:275-284

Holt, C., and D. W. L. Hukins. 1991. Structural analysis of the environment of calcium ions in crystalline and amorphous calcium phosphates by x-ray absorption spectroscopy and a hypothesis concerning the biological function of the casein micelle. Int. Dairy J. 1:151-165.

Holt, C., A. M. Kimber, B. Brooker, and J. H. Prentice. 1978. Measurements of size of bovine casein micelles by means of electronmicroscopy and light-scattering. J. Colloid Interface Sci. 65:555565.

Holt, C., and L. Sawyer. 1993. Caseins as rheomorphic proteins: Interpretation of primary and secondary structures of the $\alpha_{\mathrm{S}_{1}}$-caseins, $\beta$-caseins and $\kappa$-caseins. J. Chem. Soc. Faraday Trans. 89:26832692

Holt, C., E. S. Sorensen, and R. A. Clegg. 2009. Role of calcium phosphate nanoclusters in the control of calcification. FEBS J. 276:23082323. http://dx.doi.org/10.1111/j.1742-4658.2009.06958.x.

Holt, C., P. A. Timmins, N. Errington, and J. Leaver. 1998. A coreshell model of calcium phosphate nanoclusters stabilized by $\beta$-casein phosphopeptides, derived from sedimentation equilibrium and small-angle X-ray and neutron-scattering measurements. Eur. J. Biochem. 252:73-78.

Holt, C., M. Vankemenade, L. S. Nelson, L. Sawyer, J. E. Harries, R. T. Bailey, and D. W. L. Hukins. 1989. Composition and structure of micellar calcium-phosphate. J. Dairy Res. 56:411-416.

Holt, C., N. M. Wahlgren, and T. Drakenberg. 1996. Ability of a $\beta$-casein phosphopeptide to modulate the precipitation of calcium phosphate by forming amorphous dicalcium phosphate nanoclusters. Biochem. J. 314:1035-1039.

Horne, D. S. 2002. Casein structure, self-assembly and gelation. Curr. Opin. Colloid Interface Sci. 7:456-461. http://dx.doi.org/10.1016/ S1359-0294(02)00082-1.

Horne, D. S. 2008. Casein micelle structure and stability. Pages 133 162 in Milk Proteins. T. Abby, B. Mike, and H. Singh, ed. Academic Press, San Diego, CA.

Hurshman Babbes, A. R., E. T. Powers, and J. W. Kelly. 2008. Quantification of the thermodynamically linked quaternary and tertiary structural stabilities of transthyretin and its disease-associated variants: The relationship between stability and amyloidosis. Biochemistry 47:6969-6984. http://dx.doi.org/10.1021/bi800636q.

Jacobsen, S., T. A. Niewold, E. Kornalijnslijper, M. J. M. Toussaint, and E. Gruys. 2005. Kinetics of local and systemic isoforms of serum amyloid A in bovine mastitic milk. Vet. Immunol. Immunopathol. 104:21-31. http://dx.doi.org/10.1016/j.vetimm.2004.09.031.

Kauzmann, W. 1959. Some factors in the interpretation of protein denaturation. Adv. Protein Chem. 14:1-63.

Kawasaki, K., A.-G. Lafont, and J.-Y. Sire. 2011. The evolution of casein genes from tooth genes before the origin of mammals. Mol Biol. Evol. 28:2053-2061. http://dx.doi.org/10.1093/molbev/ msr020.

Kawasaki, K., T. Suzuki, and K. M. Weiss. 2004. Genetic basis for the evolution of vertebrate mineralized tissue. Proc. Natl. Acad. Sci. USA 101:11356-11361. http://dx.doi.org/10.1073/ pnas.0404279101.

Kawasaki, K., and K. M. Weiss. 2003. Mineralized tissue and vertebrate evolution: The secretory calcium-binding phosphoprotein gene cluster. Proc. Natl. Acad. Sci. USA 100:4060-4065. http:// dx.doi.org/10.1073/pnas.0638023100.

Khodarahmi, R., M. Beyrami, and H. Soori. 2008. Appraisal of casein's inhibitory effects on aggregation accompanying carbonic anhydrase refolding and heat-induced ovalbumin fibrillogenesis. Arch. Biochem. Biophys. 477:67-76. http://dx.doi.org/10.1016/j. abb.2008.04.028.

Knowles, T. P. J., W. M. Shu, G. L. Devlin, S. Meehan, S. Auer, C. M. Dobson, and M. E. Welland. 2007. Kinetics and thermodynamics of amyloid formation from direct measurements of fluctuations in fibril mass. Proc. Natl. Acad. Sci. USA 104:10016-10021. http:// dx.doi.org/10.1073/pnas.0610659104.

Koudelka, T., F. C. Dehle, I. F. Musgrave, P. Hoffmann, and J. A Carver. 2012. Methionine oxidation enhances $\kappa$-casein amyloid fibril formation. J. Agric. Food Chem. 60:4144-4155. http:// dx.doi.org/10.1021/jf205168t.

Koudelka, T., P. Hoffmann, and J. A. Carver. 2009. Dephosphorylation of $\alpha_{S^{-}}$and $\beta$-caseins and its effect on chaperone activity: A structural and functional investigation. J. Agric. Food Chem. 57:5956-5964. http://dx.doi.org/10.1021/jf9008372.

Kyte, J., and R. F. Doolittle. 1982. A simple method for displaying the hydropathic character of a protein. J. Mol. Biol. 157:105-132.

Lakshminarayanan, R., D. Fan, C. Du, and J. Moradian-Oldak. 2007. The role of secondary structure in the entropically driven amelogenin self-assembly. Biophys. J. 93:3664-3674. http://dx.doi org/10.1529/biophysj.107.113936.

Lemay, D. G., D. J. Lynn, W. F. Martin, M. C. Neville, T. M. Casey, G. Rincon, E. V. Kriventseva, W. C. Barris, A. S. Hinrichs, A. J. Molenaar, K. S. Pollard, N. J. Maqbool, K. Singh, R. Murney, E. M. Zdobnov, R. L. Tellam, J. F. Medrano, J. B. German, and M. Rijnkels. 2009. The bovine lactation genome: Insights into the evolution of mammalian milk. Genome Biol. 10:R43 http://dx.doi. org/10.1186/gb-2009-10-4-r43.

Lencki, R. W. 2007. Evidence for fibril-like structure in bovine casein micelles. J. Dairy Sci. 90:75-89.

Léonil, J., D. Molle, S. Bouhallab, and G. Henry. 1994. Precipitation of hydrophobic peptides from tryptic casein hydrolysate salt and pH. Enzyme Microb. Technol. 16:591-595.

Léonil, J., G. Henry, D. Jouanneau, M. M. Delage, V. Forge, and J. L. Putaux. 2008. Kinetics of fibril formation of bovine $\kappa$-casein indicate a conformational rearrangement as a critical step in the process. J. Mol. Biol. 381:1267-1280. http://dx.doi.org/10.1016/j. jmb.2008.06.064.

Le Questel, J. Y., D. G. Morris, P. H. Maccallum, R. Poet, and E. J. Milner-White. 1993. Common ring motifs in proteins involving asparagine or glutamine amide groups hydrogen-bonded to mainchain atoms. J. Mol. Biol. 231:888-896.

Little, E. M., and C. Holt. 2004. An equilibrium thermodynamic model of the sequestration of calcium phosphate by casein phosphopeptides. Eur. Biophys. J. 33:435-447. http://dx.doi.org/10.1007/ s00249-003-0376-x. 
Livney, Y. D., M. Corredig, and D. G. Dalgleish. 2003. Influence of thermal processing on the properties of dairy colloids. Curr. Opin. Colloid Interface Sci. 8:359-364.

Lopez-Fandino, R., M. Ramos, and A. Olano. 1997. Rennet coagulation of milk subjected to high pressures. J. Agric. Food Chem. 45:3233-3237. http://dx.doi.org/10.1021/jf960879v.

Lucey, J. A., and D. S. Horne. 2012. Milk salts: Technological significance. Pages 351-389 in Advanced Dairy Chemistry. Vol. 3: Lactose, Water, Salts, and Minor Constituents. 3rd ed. P. L. H. McSweeney and P. F. Fox, ed. Springer, New York, NY. 10.1007/978$0-387-84865-5$.

MacArthur, M. W., and J. M. Thornton. 1991. Influence of proline residues on protein conformation. J. Mol. Biol. 218:397-412.

Macias, M., J. S. Wiesner, and M. Sudol. 2002. WW and SH3 domains, two different scaffolds to recognize proline-rich ligands. FEBS Lett. 513:30-37.

Marchin, S., J.-L. Putaux, F. Pignon, and J. Léonil. 2007. Effects of the environmental factors on the casein micelle structure studied by cryo transmission electron microscopy and small-angle X-ray scattering/ultra-small-angle X-ray scattering. J. Chem. Phys. 126:045101 http://dx.doi.org/10.1063/1.2409933.

Margolis, H. C., E. Beniash, and C. E. Fowler. 2006. Role of macromolecular assembly of enamel matrix proteins in enamel formation. J. Dent. Res. 85:775-793.

Martin, P., P. Ferranti, C. Leroux, and F. Addeo. 2003, Non-bovine caseins: Qualitative variability and molecular diversity. Pages $277-$ 317 in Advanced Dairy Chemistry. Vol. 1A: Proteins: Basic Aspects. P. F. Fox, and P. L. H. McSweeney, ed. Kluwer Academic/ Plenum, New York, NY.

Martin-Garcia, J. M., J. Ruiz-Sanz, and I. Luque. 2012. Interfacial water molecules in SH3 interactions: A revised paradigm for polyproline recognition. Biochem. J. 442:443-451. http://dx.doi. org/10.1042/BJ20111089.

Masica, D. L., and J. J. Gray. 2009. Solution- and adsorbed-state structural ensembles predicted for the statherin-hydroxyapatite system. Biophys. J. 96:3082-3091. http://dx.doi.org/10.1016/j. bpj.2009.01.033.

Masino, L., G. Nicastro, L. Calder, M. Vendruscolo, and A. Pastore. 2011. Functional interactions as a survival strategy against abnormal aggregation. FASEB J. 25:45-54. http://dx.doi.org/10.1096/ fj.10-161208.

Matsudomi, N., Y. Kanda, Y. Yoshika, and H. Moriwaki. 2004. Ability of $\alpha_{S}$-casein to suppress the heat aggregation of ovotransferrin. J. Agric. Food Chem. 52:4882-4886. http://dx.doi.org/10.1021/ if030802o.

McMahon, D. J. 1996. Age-gelation of UHT milks: Changes that occur on storage, their effect on shelf life and the mechanism by which age-gelation occurs. Pages 315-326 in Heat Treatments and Alternative Methods. International Dairy Federation, Brussels, Belgium.

McMahon, D. J., and W. R. McManus. 1998. Rethinking casein micelle structure using electron microscopy. J. Dairy Sci. 81:2985-2993.

McMahon, D. J., and B. S. Oommen. 2008. Supramolecular structure of the casein micelle. J. Dairy Sci. 91:1709-1721. http://dx.doi. org/10.3168/jds.2007-0819.

McMahon, D. J., and B. S. Oommen. 2012. Casein micelle structure, functions and interactions. Pages 185-210 in Advanced Dairy Chemistry. Vol. 1A Proteins: Basic Aspects. 4th ed. P. F. Fox, and P. L. H. McSweeney, ed. Springer, New York, NY.

Mekmene, O., and F. Gaucheron. 2011. Determination of calciumbinding constants of caseins, phosphoserine, citrate and pyrophosphate: A modelling approach using free calcium measurement. Food Chem. 127:676-682. http://dx.doi.org/10.1016/j. foodchem.2010.12.121.

Mekmene, O., Y. Le Graet, and F. Gaucheron. 2009. A model for predicting salt equilibria in milk and mineral-enriched milks. Food Chem. 116:233-239. http://dx.doi.org/10.1016/j.foodchem.2009.02.039.

Mekmene, O., Y. Le Graet, and F. Gaucheron. 2010. Theoretical model for calculating ionic equilibria in milk as a function of $\mathrm{pH}$ :
Comparison to experiment. J. Agric. Food Chem. 58:4440-4447. http://dx.doi.org/10.1021/jf903628r.

Mezei, M., P. J. Fleming, R. Srinivasan, and G. D. Rose. 2004. Polyproline II helix is the preferred conformation for unfolded polyalanine in water. Proteins 55:502-507. http://dx.doi.org/10.1002/ prot.20050.

Miranda, G., M. F. Mahe, C. Leroux, and P. Martin. 2004. Proteomic tools to characterize the protein fraction of Equidae milk. Proteomics 4:2496-2509. http://dx.doi.org/10.1002/pmic.200300765.

Morgan, P. E., T. M. Treweek, R. A. Lindner, W. E. Price, and J. A. Carver. 2005. Casein proteins as molecular chaperones. J. Agric. Food Chem. 53:2670-2683. http://dx.doi.org/10.1021/jf048329h.

Musacchio, A. 2002. How SH3 domains recognize proline. Adv. Protein Chem. 61:211-268.

Naganagowda, G. A., T. L. Gururaja, J. Satyanarayana, and M. J. Levine. 1999. NMR analysis of human salivary mucin: MUC7 derived O-linked model glycopeptides: Comparison of structural features and carbohydrate-peptide interactions. J. Pept. Res. 54:290-310. http://dx.doi.org/10.1034/j.1399-3011.1999.00102.x.

Newman, A. M., and J. B. Cooper. 2011. Global analysis of prolinerich tandem repeat proteins reveals broad phylogenetic diversity in plant secretomes. PLoS ONE 6:e23167 http://dx.doi. org/10.1371/journal.pone.0023167.

Nickerson, S. C., L. M. Sordillo, N. T. Boddie, and A. M. Saxton. 1985. Prevalence and ultrastructural characteristics of bovine mammary corpora amylacea during the lactation cycle. J. Dairy Sci. 68:709-717.

Niewold, T. A., C. L. Murphy, C. A. M. Hulskamp-Koch, P. C. J. Tooten, and E. Gruys. 1999. Casein related amyloid, characterization of a new and unique amyloid protein isolated from bovine corpora amylacea. Amyloid 6:244-249.

Oftedal, O. T. 2012. The evolution of milk secretion and its ancient origins. Animal 6:355-368. http://dx.doi.org/10.1017/ S1751731111001935.

On-Nom, N., A. S. Grandison, and M. J. Lewis. 2010. Measurement of ionic calcium, $\mathrm{pH}$, and soluble divalent cations in milk at high temperature. J. Dairy Sci. 93:515-523. http://dx.doi.org/10.3168/ jds.2009-2634.

Ossowski, S., A. Jackson, M. Obiols-Rabasa, C. Holt, S. Lenton, L. Porcar, M. Paulsson, and T. Nylander. 2012. Aggregation behavior of bovine $\kappa$ - and $\beta$-casein studied with small angle neutron scattering, light scattering, and cryogenic transmission electron microscopy. Langmuir 28:13577-13589. http://dx.doi.org/10.1021/ la302416p.

Ouanezar, M., F. Guyomarc'h, and A. Bouchoux. 2012. AFM Imaging of milk casein micelles: Evidence for structural rearrangement upon acidification. Langmuir 28:4915-4919. http://dx.doi. org/10.1021/la3001448.

Payens, T. A. J., and H. J. Vreeman. 1982. Casein micelles and micelles of $\kappa$ - and $\beta$-casein. Pages 543-571 in Solution Behavior of Surfactants, Vol. 1. K. L. Mittal, ed. Plenum, New York, NY.

Pearce, F. G., S. H. Mackintosh, and J. A. Gerrard. 2007. Formation of amyloid-like fibrils by ovalbumin and related proteins under conditions relevant to food processing. J. Agric. Food Chem. 55:318-322. http://dx.doi.org/10.1021/jf062154p.

Piantoni, P., P. Wang, J. K. Drackley, W. L. Hurley, and J. J. Loor. 2010. Expression of metabolic tissue remodeling, oxidative stress, and inflammatory pathways in mammary tissue during involution in lactating dairy cows. Bioinform. Biol. Insights 4:85-97. http:// dx.doi.org/10.4137/BBI.S5850

Polverini, E., G. Rangaraj, D. S. Libich, J. M. Boggs, and G. Harauz. 2008. Binding of the proline-rich segment of myelin basic protein to SH3 domains: Spectroscopic, microarray, and modeling studies of ligand conformation and effects of posttranslational modifications. Biochemistry 47:267-282. http://dx.doi.org/10.1021/ bi701336n.

Portnaya, I., U. Cogan, Y. D. Livney, O. Ramon, K. Shimoni, M. Rosenberg, and D. Danino. 2006. Micellization of bovine $\beta$-casein studied by isothermal titration microcalorimetry and cryogenic transmission electron microscopy. J. Agric. Food Chem. 54:55555561. http://dx.doi.org/10.1021/jf060119c. 
Pouliot, Y., M. Boulet, and P. Paquin. 1989a. Observations on the heat-induced salt balance changes in milk. 1. Effect of heating time between $4^{\circ} \mathrm{C}$ and $90^{\circ} \mathrm{C}$. J. Dairy Res. 56:185-192.

Pouliot, Y., M. Boulet, and P. Paquin. 1989b. Observations on the heat induced salt balance changes in milk. 2. Reversibility on cooling. J. Dairy Res. 56:193-199.

Qi, P. X., E. D. Wickham, E. G. Piotrowski, C. K. Fagerquist, and H. M. Farrell. 2005. Implication of C-terminal deletion on the structure and stability of bovine $\beta$-casein. Protein J. 24:431-444. http://dx.doi.org/10.1007/s10930-005-7639-6.

Rasmussen, L. K., L. B. Johnsen, A. Tsiora, E. S. Sørensen, J. K. Thomsen, N. C. Nielsen, H. J. Jakobsen, and T. E. Petersen. 1999. Disulphide-linked caseins and casein micelles. Int. Dairy J. $9: 215-218$

Regini, J. W., H. Ecroyd, S. Meehan, K. Bremmell, M. J. Clarke, D. Lammie, T. Wess, and J. A. Carver. 2010. The interaction of unfolding $\alpha$-lactalbumin and malate dehydrogenase with the molecular chaperone $\alpha$ B-crystallin: A light and X-ray scattering investigation. Mol. Vis. 16:2446-2456.

Regnault, S. E. Dumay, and J. C. Cheftel. 2006. Pressurisation of raw skim milk and of a dispersion of phosphocaseinate at $9^{\circ} \mathrm{C}$ or $20^{\circ} \mathrm{C}$ : Effects on the distribution of minerals and proteins between colloidal and soluble phases. J. Dairy Res. 73:91-100. http://dx.doi. org/10.1017/S0022029905001494.

Rijnkels, M., L. Elnitski, W. Miller, and J. M. Rosen. 2003. Multispecies comparative analysis of a mammalian-specific genomic domain encoding secretory proteins. Genomics 82:417-432. http:// dx.doi.org/10.1016/s0888-7543(03)00114-9.

Rose, G. D. 2002. Unfolded proteins. Pages 1-398 in Advances in Protein Chemistry. Vol. 62. F. M. Richards, D. S. Eisenberg, and J. Kuriyan, ed. Academic Press, Amsterdam, the Netherlands.

Schedlbauer, A., P. Ozdowy, G. Kontaxis, M. Hartl, K. Bister, and R. Konrat. 2008. Backbone assignment of osteopontin, a cytokine and cell attachment protein implicated in tumorigenesis. Biomol. NMR Assign. 2:29-31. http://dx.doi.org/10.1007/s12104-0079076-2.

Schenkels, L. C., E. C. I. Veerman, and A. V. N. Amerongen. 1995 Biochemical composition of human saliva in relation to other mucosal fluids. Crit. Rev. Oral Biol. Med. 6:161-175.

Schleinkofer, K., U. Wiedemann, L. Otte, T. Wang, G. Krause, H. Oschkinat, and R. C. Wade. 2004. Comparative structural and energetic analysis of WW domain-peptide interactions. J. Mol. Biol. 344:865-881. http://dx.doi.org/10.1016/j.jmb.2004.09.063.

Senapati, S., S. Das, and S. K. Batra. 2010. Mucin-interacting proteins: From function to therapeutics. Trends Biochem. Sci. 35:236-245. http://dx.doi.org/10.1016/j.tibs.2009.10.003.

Shekar, P. C., S. Goel, S. D. S. Rani, D. P. Sarathi, J. L. Alex, S. Singh, and S. Kumar. 2006. $\kappa$-Casein-deficient mice fail to lactate. Proc. Natl. Acad. Sci. USA 103:8000-8005. http://dx.doi. org/10.1073/pnas.0601611103.

Shewry, P. R., and N. G. Halford. 2002. Cereal seed storage proteins Structures, properties and role in grain utilization. J. Exp. Bot. 53:947-958. http://dx.doi.org/10.1093/jexbot/53.370.947.

Stothart, P. H. 1989. Subunit structure of casein micelles from smallangle neutron scattering. J. Mol. Biol. 208:635-638.

Stothart, P. H., and D. J. Cebula. 1982. Small-angle neutron scattering study of bovine casein micelles and sub-micelles. J. Mol. Biol. 160:391-395

Stranks, S. D., H. Ecroyd, S. van Sluyter, E. J. Waters, J. A. Carver, and L. von Smekal. 2009. Model for amorphous aggregation processes. Phys. Rev. E Stat. Nonlin. Soft Matter Phys. 80:051907 http://dx.doi.org/10.1103/PhysRevE.80.051907.

Sudol, M. 1998. From Src homology domains to other signaling modules: Proposal of the 'protein recognition code'. Oncogene 17:1469-1474. http://dx.doi.org/10.1038/sj.onc.1202182.

Syme, C. D., E. W. Blanch, C. Holt, R. Jakes, M. Goedert, L. Hecht, and L. D. Barron. 2002. A Raman optical activity study of rheomorphism in caseins, synucleins and tau- New insight into the structure and behavior of natively unfolded proteins. Eur. J. Biochem. 269:148-156. http://dx.doi.org/10.1046/j.0014-2956.2001.02633.x.
Teoh, C. L., I. B. Bekard, P. Asimakis, M. D. W. Griffin, T. M. Ryan, D. E. Dunstan, and G. J. Howlett. 2011. Shear flow induced changes in apolipoprotein C-II conformation and amyloid fibril formation. Biochemistry 50:4046-4057. http://dx.doi.org/10.1021/ bi2002482.

Thorn, D. C., H. Ecroyd, and J. A. Carver. 2009. The two-faced nature of milk casein proteins:amyloid fibril formation and chaperone-like activity. Aust. J. Dairy Technol. 64:34-40.

Thorn, D. C., H. Ecroyd, M. Sunde, S. Poon, and J. A. Carver. 2008. Amyloid fibril formation by bovine milk $\alpha_{\mathrm{S}^{2}}$-casein occurs under physiological conditions yet is prevented by its natural counterpart, $\alpha_{\mathrm{S} 1}$-casein. Biochemistry 47:3926-3936. http://dx.doi. org $/ 10.1021 /$ bi701278c.

Thorn, D. C., S. Meehan, M. Sunde, A. Rekas, S. L. Gras, C. E. MacPhee, C. M. Dobson, M. R. Wilson, and J. A. Carver. 2005 Amyloid fibril formation by bovine milk $\kappa$-casein and its inhibition by the molecular chaperones $\alpha_{\mathrm{S}}$-and $\beta$-casein. Biochemistry 44:17027-17036. http://dx.doi.org/10.1021/bi051352r.

Thornton, D. J., K. Rousseau, and M. A. McGuckin. 2008. Structure and function of the polymeric mucins in airways mucus. Annu. Rev. Physiol. 70:459-486. http://dx.doi.org/10.1146/annurev. physiol.70.113006.100702.

Tompa, P. 2010. Structure and Function of Intrinsically Disordered Proteins. Chapman \& Hall/CRC Press, Boca Raton, FL.

Trejo, R., T. Dokland, J. Jurat-Fuentes, and F. Harte. 2011. Cryotransmission electron tomography of native casein micelles from bovine milk. J. Dairy Sci. 94:5770-5775. http://dx.doi. org/10.3168/jds.2011-4368.

Treweek, T. M., D. C. Thorn, W. E. Price, and J. A. Carver. 2011. The chaperone action of bovine milk $\alpha_{\mathrm{S}^{-}}$and $\alpha_{\mathrm{S}^{2}}$-caseins and their associated form $\alpha_{\mathrm{S}}$-casein. Arch. Biochem. Biophys. 510:42-52. http://dx.doi.org/10.1016/j.abb.2011.03.012.

Uversky, V. N. 2008. Amyloidogenesis of natively unfolded proteins. Curr. Alzheimer Res. 5:260-287. http://dx.doi. org/10.2174/156720508784533312.

Uversky, V. N., and A. K. Dunker. 2010. Understanding protein nonfolding. Biochim. Biophys. Acta 1804:1231-1264. http://dx.doi. org/10.1016/j.bbapap.2010.01.017.

Uversky, V. N., and A. L. Fink. 2004. Conformational constraints for amyloid fibrillation: The importance of being unfolded. Biochim. Biophys. Acta. Proteins Proteomics 1698:131-153. http://dx.doi. org/10.1016/j.bbapap.2003.12.008.

Vendruscolo, M., T. P. J. Knowles, and C. M. Dobson. 2011. Protein solubility and protein homeostasis: A generic view of protein misfolding disorders. Cold Spring Harb. Perspect. Biol. 3:a010454 http://dx.doi.org/10.1101/cshperspect.a010454.

Waugh, D. F., and B. Talbot. 1971. Equilibrium casein micelle systems. Biochemistry 10:4153-4162.

Yong, Y. H., and E. A. Foegeding. 2010. Caseins: Utilizing molecular chaperone properties to control protein aggregation in foods. J. Agric. Food Chem. 58:685-693. http://dx.doi.org/10.1021/ jf903072g.

Zhang, X., B. E. Ramirez, X. Liao, and T. G. H. Diekwisch. 2011. Amelogenin supramolecular assembly in nanospheres defined by a complex helix-coil-PPII helix 3d-structure. PLoS ONE 6:e24952 http://dx.doi.org/10.1371/journal.pone.0024952.

Zhang, X. F., X. M. Fu, H. Zhang, C. Liu, W. W. Jiao, and Z. Y. Chang. 2005. Chaperone-like activity of $\beta$-casein. Int. J. Biochem. Cell Biol. 37:1232-1240. http://dx.doi.org/10.1016/j.biocel.2004.12.004.

Zhao, P., C. H. Nguyen, and P. Chidiac. 2010. The proline-rich N-terminal domain of G18 exhibits a novel G protein regulatory function. J. Biol. Chem. 285:9008-9017. http://dx.doi.org/10.1074/ jbc.M109.057174. 